\title{
AMERICAN INSTITUTE OF ELECTRICAL
}

ENGINEERS.

Vol. V. New York, February, 1888. No. 5.

\section{Special Meetivg.}

Held at the House of the American Society of Civil Engineers, 127 East 23rd Street, New York, December 20, 1887.

The meeting was called to order at 8 o'clock, P. M., by the President, Mr. T. C. Martin.

The President :-I am very glad that, in spite of the inclemency of the weather, we have so large an attendance this evening of those who are genuinely interested in this question of patent reform. The subject of the revision of the patent law will be brought before us this evening by Mr. Arthur Stenart, who is the general legal counsel of the National Electric Light Association. The subject is one, I may say, that lies well within the province and jurisdiction of the American Institute of Electrical Engineers. The subject has been brought before us on various occasions; and it is somewhat interesting to recall the fact, that at our very first meeting held in this room for purposes of organization, now close upon four years ago, almost the first question that was introduced to our notice, was that of Patent Reform, when Mr. C. J. Kintner, of the Patent Office, presented a spirited appeal to us for aid in bringing about certain reforms which he then deemed necessary. Since that time we have had valuable and forcible papers presented before the Institute by Mr. Frankland Jannus and by Mr. A. C. Fowler, both of whom brought out very ably the necessities of the situation at the time. It will thus be seen that the Institute is well prepared to consider the subject in all its bearings and relations, and is ready to ascertain from Mr. Steuart just what work the National Electric Light Association now proposes to do, with regard to this bill to be introduced before Congress. I may say here that I have myself had the opportunity of attending all the meetings of the National Electric Iight Association, at which this question has been brought for- 
ward, and I think I may take the liberty of saying that that society does not intend to act with any undue haste or precipitancy in the matter, but is likely, in fact is sure, to move with its accustomed practicability and business-like common sense. Our position to-night is one in which we may be able to do great good in the direction of showing how far this movement is calculated to receive the support and sympathy of scientific and professional circles, especially those that are connected with electrical interests. I have much pleasure, therefore, in asking Mr. Arthur Steuart to read us his paper on Revision of the Patent Law. 


\section{REVISION OF THE PATENT LAW.}

BY ARTHUR STEUART.

I come before you this evening at the invitation of your Secretary, for the purpose of telling you of the effort that is being made by the National Electric Light Association, to secure some reforms in the Patent laws of this country and of attempting to get you to join hands with us in carrying these reforms into effect. I particularly desire that the suggestions I shall make may be fully discussed by those present, for I hope to gain many valuable suggestions from you. For the purpose, therefore, of presenting what I have to say in the shortest possible time, so as to leave as much as possible for other gentlemen, I have condensed my suggestions and shall state them with very little argument; first, for lack of time, and secondly, that I think most of the reforms suggested are so apparent that they will call forth little opposition. But before proceeding to discuss the details of the law that require changes and additions, I cannot refrain from making a few remarks upon the patent system in general and its influence upon the industrial development of our country. Who can measure the benefits that this land has derived from the inventions that have been produced by its citizens. The roll of honor is too long to be repeated. The cotton gin, the printing press, the reaper, the application of steam to all the uses of civilization, and latest but not least, the modern application of electricity in its multitudinous forms; but while these brilliant achievements occupy our attention, we must not overlook the thousands upon thousands of inventions relating to matters of detail in every industry that have cheapened the product by saving time, material, power or labor. The fact is apparent that our advancement as a manufacturing nation has been due to the introduction of new methods of work which have enabled us to produce staples at such a price as to compete with other nations in 
the markets of the world, or in the development of new devices which have supplanted old ones or created a market for themselves. This being true, we must look for a cause for this development. What has induced the people of this country to create so many new things, to labor so long and arduously to lessen the cost of production of some article, or to supply a new one to take its place which is better or cheaper?

I think we may state it as a proposition that will not meet with denial, that the prevailing motive of the American people is a motive of pecuniary gain, a desire to amass wealth, to attain power by means of money, and whatever avenue offers them this reward will be the one into which they will press with a vigor and determination that knows no such thing as failure.

When the framers of our Constitution inserted into it the clause which provides that "Congress shall have power to promote the progress of science and the useful arts, by securing * * for limited times to $* * *$ inventors the exclusive right to their $* * *$ discoveries," they laid a foundation stone upon which an edifice has been constructed, that has far surpassed anything they had conceived. Upon this provision of the Constitution is our Patent Law based; from it, it takes its spirit; and with the view of adhering more closely to this spirit, have the amendments to the Patent Law been suggested, to which I shall ask your attention this evening.

The patent laws of the United States, passed in pursuance of this provision of the Constitution, open ap before every citizen of this country, as well as before those of many others, opportunities of obtaining wealth and power that are not presented by any other set of circumstances under the sun. In a single moment of time, by a quick operation of the mind, the poor mechanic may be put into possession of an idea that, by its own development, may place him among the princes of the land. This is the possibility that presents itself to every man, rich or poor, high or low, who comes to understand the meaning of our patent system and its results. What force can be compared with this, to produce in the minds of men, thought, deep, concentrated and continuous, for the production of inventions, a thirst for knowledge, and a frugality of life that will supply a surplus of funds for the acquisition of knowledge and the development of inventions, and an ambition for their children that they shall have greater advantages of education upon which to work than their parents. And who can 
estimate the value to a state of such influence upon its citizens. This training, foreign manufacturers testify, produces in American operatives a power of comprehending their work, and a rapidity and dexterity of workmanship, that makes it impossible for them, with labor at one-half the cost and their factories fitted with the latest American machines, to produce the same goods as cheaply as they can be produced in this country.

It therefore goes without saying, that with such inestimable good to the nation, both in improving its industries and its people, to be attained by stimulating inventors to their highest effort, that the only true course for the law-makers to pursue in framing legislation relative to this subject, is to endeavor to make the process of obtaining a patent upon an invention as quick, easy and inexpensive as possible, and after it is granted to throw around it, in the hands of its owner, every form of protection known to the law, that will enable him to realize the full intent of the Constitution and enjoy the exclusive right to make, use and vend the invention.

Our patent system, as it exists to-day, is a grand structure, but it has some defects, which are due principally to the fact, that the demands made upon it by the development of our industries have far exceeded anything that the framers of the present law contemplated.

The Patent Law of to-day is substantially identical with the law passed by Congress in 1836. This law was revised in 1870, and codified in 1874; but few changes were made in it, and little, if any, provision was made, to accommodate the immense mass of business that has been cast upon the Patent Office; and some of the new features that were introduced have been found to work a hardship upon inventors rather than a benefit; so that practi cally we are working under a law formulated fifty years ago, when the work of the Patent Office for the whole year was something less than it is to-day for each week. Is it surprising, therefore, that the child should have outgrown his clothes? And this is practically just what has taken place. A commissioner and a half-dozen examiners were quite equal to the task of examining intelligently four hundred and fifty patents a year; but the case is a very different one, when the Commissioner has under him something like two hundred examiners, and when the annual issue of the office is something over 25,000 patents.

If time permitted, I could show you how utterly impossible it is, for the work of the Patent Office to be accomplished, with any 
degree of satisfaction to the public, under the prevailing organization; but I know that most of you are quite as well aware as I am, of the defects that exist and are quite as much interested in removing them. I shall pass at once to the consideration of the measures of reform that seem desirable in the Patent Office.

I. THE PATENT OFFICE SHOULD HAVE THE EXClusive UsE OF ITS BUILDING.

All those who have had any experience with the internal operations of the Patent Office are aware of the fact that this office is greatly cramped for space. The examiners are often crowded into rooms that are so small that there is scarcely space enough between the desks to move about. Many of the officers and employees are compelled to work in quarters that are unfit for human habitation; simply because there is no other place to put them; and the documents and records of the office are so crowded, and the places in which they are kept are so unfit for their accomodation that they are in constant danger of destruction. The Patent Office building was constructed with money, every dollar of which was paid to the Government by patentees and applicants for patents, and yet the Patent Offlce is crowded into less than half of this building. The Interior Department, with its Land Office and Indian Department, occupy the balance and are constantly encroaching.

The Interior Department should have separate quarters and the Patent Office should have the whole of the building which will not more than accommodate it.

II. ThE PATENT OFFICE SHOUld HAVE THE WHOLE OF ITS OWN INCOME.

For the past fifty years, the Patent Office has paid all of its own expenses, has built its own building, and in addition to this, has paid the Government an annual revenue, which aggregates today, without interest, something over three millions of dollars. And yet the most difficult task that the Commissioners of Patents have had to perform, has been to induce Congress to authorize the expenditure of a part of this revenue for the necessary expenses of the Patent Office. For the proper dispatch of the work of the Patent Office, considerable additional force is necessary. The Commissioner of Patents should be authorized to expend the whole of the income of the office for its own expenses, and what 
was not spent should be set aside as a fund to be used for the benefit of the office at any time that it is needed.

III. EXAMINERS.

The staff of examiners in the Patent Office have charge of public interests of a most vital nature. They are the virtual judges of whether an inventor shall have a patent for his invention at all, and also of what kind of a patent he shall have in case they give him any.

It is therefore apparent that in order that they may perform their duties with intelligence and efficiency they must fulfil several conditions.

1st. They must be thoroughly educated in the technology of the arts and sciences, and in the Patent Law. Experience has shown that this training can only he acquired in one or two ways,-either by systematic teaching or by years of experience in the practical work of the Patent Office; the latter method is the one now in operation and it results in creating a class of Examiners who are undergoing the process of education at the expense of the unfortunate inventor whose case may fall into their hands. The inventors of the country have a right to demand that this system of education of examiners at their expense be discontinued and a system adopted that will secure to the Patent Office a corps of examiners who will be thoroughly trained before they enter the office, and to the inventor the examination of his case by a man fully equipped to make such examination in the best manner.

2nd. Having obtained a staff of competent and thoroughly equipped examiners, they must be retained in office, so that the public may have the benefit of their services through a number of years. The Army and Navy have long since solved this problem by the exercise of a system of education, compensation, promotion and retirement on pay, which fully secures these ends. Why should not that system, so successful in one branch of the Government service, be established to secure similar and equally necessary results in the Patent Office?

3rd. The examiners should be relieved from all political influence. Civil service reform has attacked the question of political interference with Patent Office appointments with little success. The evils from this cause now existing are great and call loudly for remedy. The Army and Navy system put those 
departments of the public service almost entirely beyond the reach of the politicians. Thus it should be with the Patent Office.

\section{SALARY OF COMMISSIONER OF PATENTS.}

The salary of the Commissioner of Patents should be very high, so that every examiner may feel that if he is faithful and does his duty, he may some day, in the natural order of promotion, reach a place of honor and large emoluments. This is the system of the Army and Navy, and in those departments it works admirably.

\section{A PATENT COURT SHOLLD BE ESTABLISHED.}

The greatest evil that exists to-day in the administration of the patent system, lies in the lack of harmony between the Patent Office and the Courts of the United States, in which infringement cases are determined. Every practitioner before the Patent Office knows how little regard is paid by the Examiners to the decisions of the courts upon questions of Patent Law, and it has long since become a thing of the past, when the courts give any weight to the presumption of patentability, that would naturally arise from the fact of the Commissioner of Patents having granted a patent upon a device. For the accomplishment of the best results with our patent system, the interpretations and application of the law under which patents are granted should be the same as that under which rights growing out of patents are determined. So that a right granted by the Patent Office, would be sustained by the Courts, and the rulings of the courts would be in conformity with the spirit of the Constitution which has originated the whole system.

Under the existing system the examiners in the Patent Office interpret the Patent Law for themselves; and it has been my experience that few of them agree upon many points. The practical questions, which have to be passed upon by the examiners, seldom, if ever, get before the Circuit Courts, but are decided by the Commissioners of Patents, who it is well known, seldom possess any knowledge of Patent Law when they enter upon the duties of the office, and seldom occupy the position long enough, to be of any practical service to the office after they have learned something of the law by experience. The result is, that a majority of the cases passed upon by the commissioners and which are intended for the guidance of the examiners, are decided at a 
time when the particular Commissioner is almost entirely ignorant of both the law and the practice of the office. It is, therefore, only to be expected that the examiners should form their own notions of the law and pay little regard to either Court or Commissioner, and as the examiners are not lawyers and have no knowledge of the Patent Law, except such as they may gain from the conflicting decisions of the ever changing commissioners; and as they have had no judicial training, it follows as a matter of course that each primary examiner has his own interpretation of the law and his own peculiar notions of how it should be applied to the practical questions that arise in his daily work. The resnlt is that we have as many different patent offices as we have divisions, and scarcely any two of them with the same views of the law, but each having the power, and exercising it, of issuing patents according to his own individual notion of what the patent should contain and how it should be framed, and these patents thus issued are the title papers upon which the inventors of the country are compelled to base their claim, when they come into the courts for the purpose of protecting their property. Is there any wonder that it is difficult to obtain a patent of any value, or to sustain and protect it after it is procured? It seems, therefore, to be eminently desirable that the same tribunal (which shall be so framed as to insure its capacity) should have appellate jurisdiction from both the Patent Office and the Circuit Courts, so that by vesting both jurisdictions in one competent court, the rulings of both branches, the Patent Office and the Circuit Courts, may be made uniform and the anomaly removed that now exists of one branch of the Government employed in granting patents; and another, in destroying them; it may be said that such a Court exists at this time, but we all know how far removed the Supreme Court of the United States is from the Patent Office and how little influence it has upon its practice; beside which, the existing evils have grown up under the present system which demonstrates its incapacity to remedy them. A strong, well selected Court of expert patent lawyers would have many advantages. It would harmonize the Patent Office and the Circuit Courts. It would crystallize the practice of the Patent Office, so that it would be possible for attorneys to form some conception of what that practice is and be able to advise their clients with safety with reference to their rights. The inventor could have some hope that when he had complied with his part of the government con- 
tract, by disclosing his secret, he would be protected in the exclusive right to use it. Such a court would lift a great burden from the shoulders of the Supreme Court, as but a small proportion of cases decided by it would be appealed to that court, and its rulings being binding upon the circuit courts would enormously simplify the practice in those courts.

The jurisdiction of such a court should be altogether appellate and should consist in appeals from the Board of Examiners-inChief upon question of anticipation, patentability and practice, from the Examiners of Interference, upon questions of priority between applicants for patent upon the same invention, and of appeals from the circuit courts of the United States upon all questions relating to patents that now go to the Supreme Court. It would be proper also to include, within the jurisdiction of this court, all questions now passed upon by the Commissioner of Patents, such as trade-marks and labels; copy-rights might also be included. With such a court the duties of the Commissioner of Patents should be purely executive and the jurisdiction of the Supreme Court of the District of Columbia in matters of appeal from the Commissioner, should be cut off. The Supreme Court of the District, should bear the same relation to this court as the circuit courts.

Passing from the question of the reorganization of the Patent Office to specific amendments to the law, the first question that presents itself is the question of limitation to actions.

\section{LIMITATIONS.}

It is pretty well settled by the courts that, since the adoption of the Revised Statutes 1874, there has been no limitation to the right of an owner of a patent to bring suit against an infringer for the recovery of damages for such infringement. Prior to that time, the only limitation that existed was six years after the expiration of the patent--and this seems to be the just rulemany rules for limitation have been suggested, but it seems to me, in view of the fact which all of us have experienced, that the last few years of a patent are often the only ones during which the inventor realizes anything from his invention, that to cut him off from the recovery of damages from infringers, who may have pirated his invention during a period when he was too poor to stop them, would be unjust in the extreme. 


\section{DAMAGES.}

The existing equity rules, for the recovery of profits and damages for the infringement of a patent, are in very satisfactory shape; but since the decision of the Supreme Court in Root vs. The Railroad Company, these rules do not apply to actions brought for the recovery of damages after the expiration of the patent. Such suits must be brought at law, by an action of trespass on the case, and the measure of damages under that form of action are much less liberal than the rule in equity. In an action of trespass on the case, the measure of damages is the actual loss to the plaintiff and not the gain to the defendant; while in equity the rule allows the recovery of either, loss to the plaintiff or the gain of the infringer, whichever may be the greater, and often the difference is very great. If it is just and right that the owner of a patent should have all the benefits that may or can be derived from the use of his invention, and this is the theory of the law, and in one form of action before the expiration of his patent is allowed to recover these benefits, in the absence of a statute of limitations, why, in justice should he be deprived of this benefit simply by the expiration of his patent? It would seem as if this evil should be remedied by legislation. It might be done by giving a plaintiff a standing in equity, under a bill for an account and discovery independent of an injunction; or if the patentee were permitted to bring an action of assumpsit, for recovery of the benefit that the infringer had derived by the use of his invention, this might be almost as well; but this would require the interposition of a jury, and in complicated patent cases it is difficult to accomplish satisfactory results with a jury. It is almost impossible to make a jury understand mechanical technicalities, or for the attorneys to do justice to the case upon oral testimony.

We have at this time a case in point which illustrates this rule. For seven years the owners of certain patents have been in constant litigation, seeking to sustain them. We have recently succeeded in getting a decree in their favor, and a month before this decree was rendered the patents expired. The patents have been extensively infringed and cover important inventions. We have now no remedy save to sue at law by an action of trespass on the case. As a matter of fact the owners of the patents have never established a license fee for their use, but if they had, 
as they might have done, it would not probably, have been more than $\$ 10$, for each machine, hence this sum in our action at law would have been the limit of our possible recovery; notwithstanding the fact that the infringer by the use of each machine has saved to himself no less than $\$ 500$. Why should the rule of law in a case like this be different from that, in a case where a man without my knowledge or against my will carries off my horse and uses him for his own benefit for a certain period, after which I recover him. In such a case, I bring a suit and the jury estimate the benefit that the wrong doer has derived from the use of my horse and award me this amount as damages for his wrongful act. Would it be right that this wrong doer should have the power of escaping liability, by answering when the jury found that he had made $\$ 100$ by the use of my horse, that I could not in the same time have made but $\$ 10$ with him? Would not this be putting a premium upon the wrongful act?

The question is still an open one, whether in those states where the common law forms of action have been abolished, an action could be maintained at law for the infringement of a patent the substantial result of which would be the same as the common law action of assumpsit, although the statute prescribes an action of trespass on the case as the proper action.

\section{REISSUES.}

Since the decisions of the Supremə Court in Miller vs. The Bridgeport Brass Company and the line of cases that have confirmed this doctrine, it may be said that a reissue in the sense in which that term was formerly applied, is no longer possible. The unfortunate inventor who has employed in his ignorance, an incompetent solicitor to procure his patent, or who yields to the unnecessary limitations of the office, and whose patent issues to him covering half of his invention, or possibly contains a disclaimer disclaiming the other half, can be said to-day to have no remedy for his misfortune; and if two years have elapsed since he procured his patent, or. some enterprising manufacturer examines his patent, and finding that he has not covered the second half of his invention, proceeds to make and sell that half, he is for ever barred from going back and claiming it. Some change in the law should surely be made, to enable an innocent and meritorious inventor to secure the full benefit of his invention, if this can be done without destroying vested property rights in individuals. 
Under the present law, when a patent is surrendered in order to obtain a reissue, all accrued causes of action for past infringement upon the original patent go with it, and no action can be brought for an infringement committed prior to the date of the reissue. There does not appear to be any good reason for the existence of this rule.

At present an application for a reissue must be signed and sworn to by the inventor. This rule puts it into the power of a dishonest person to extrac: money from the owner of the patent by refusing to sign the reissue papers. The owner of a patent should have the power to deal with his property as he chooses, and as he is considered, when he purchased the patent, to have purchased all that could have been covered by the inventor's original application, if the patent does not do this, he should have the power to reissue his patent upon his own petition, and an oath that he is the sole owner, or if there be several, that they own the whole title.

IX. REPEAL OF PATENTS.

The statutes of the United States contains no provision which will permit a patent, supposed to have been obtained by fraud or mistake, to be set aside, nor for any action by the United States against the owner of such a patent to prove the fraud and have the patent declared void. The statute should contain such a provision.

\section{EQUTTY PROCEEDINGS FOR SLANDER TO PATENT.}

Neither statute nor precedent in this country authorizes an equity proceeding for an injunction to restrain the continuance of slander against a machine or a patent, by one who falsely charges that the machine or the patent is an infringement of another patent owned by him, and threatens suit for such infringement, but neglects to bring such suit, and who thus continues to disturb the business of the party slandered, without attempting to execute his threats or to vindicate his claim. Such an injury cannot adequately be remedied by an action at law for damages; what is wanted is an injunction from a Court of Equity to stop the tongue of the slanderer at once and forever.

XI. LICENSES.

Licenses should be recorded and subject to the same rules as mortgages of land, the license first recorded should take precedence. 
XII. JOINT OWNERS.

The mutual rights of joint owners of a patent are in a very unsettled state in the present condition of the law, and it would, I think, be much safer to say that joint owners are entirely independent of one another, although there are some cases to the contrary, than to venture any statement, with reference to what those mutual rights may be.

It would seem that no good reason could be advanced why joint owners of a patent should not bear the same relation to one another as joint owners of any other property. If two persons own a house jointly, but in definite proportions, and one of those persons rents the house and receives the rent for it, the other can of course receive his share of the rent either from the person or from the property. The absence of well settled rules upon this subject makes it very desirable that they should be established by statute.

XiIr. United States patent limited by foreign patent.

United States patents should not be limited to expire with the shortest lived foreign patent upon the same invention for the simple reason that the American inventor who gives his invention as a free gift to the foreigner, gets a patent here for seventeen years, while he who seeks to protect himself abroad may limit his United States patent by several years.

XIV. ASSIGNMENTS.

Assignments of patents should stand upon the same footing as conveyances of land, the assignment first recorded should take precedence.

\section{EXPENSE OF LITIGATION.}

Expense of the trial of patent cases might be lessened if the Court was authorized, in impannelling a jury as provided by the act of 1875 , to impannel a jury of five experts in the subject matter of the case, pay them a suitable per diem, let them hear the testimony, and advise the Court.

\section{INTERNATIONAL CONVENTION.}

The United States, by its adherence to the International Convention, pledged itself to adopt legislation as soon as possible to harmonize the existing law of this country with the international law. The practical result that Americans need in relation to foreign patents is a period of say six months, after they have 
secured an allowance of their United States patent, to make their applications abroad without affecting the term of their United States patent.

I have thus rapidly touched upon the points in our Patent Law that need revision, without attempting to formulate specific additions to the statutes. This, I think, can only be done effectually by a commission of expert lawyers, such as is contemplated by the bill that we propose to introduce into Congress. In order to secure the passage of that bill, we will need the aid of every man who is interested in this subject exerted to the fullest extent, we would most earnestly urge the importance of this effort in its possible effects upon the country, and solicit your assistance in making it successful.

DISCUSSION.

The President :-Mr. Steuart's weighty paper is now before us for discussion. On such an occasion as this, when we have so many views to be represented, we shall be very glad to have the participation in the discussion of gentlemen who are interested, but who may not be members of the Institute, and before we proceed, I think I express the general wish when I call upon Mr. George Ticknor Curtis to open the discussion for us. Mr. Curtis is known to all of us as a foremost student and exponent of patent law in this country, and it would be of the greatest pleasure to us all to learn from him what his views are of the subject in general, and what are the specific points to which he considers it best for us to direct our attention in seeking any reform of the system. Mr. Curtis, we should be very happy indeed if you would favor us.

Mr. CurTis:-Mr. Chairman, I have listened with the greatest interest to the very able and comprehensive paper which has been read. It is a subject that has occupied my thoughts and exertions for a good many years. A year ago, last winter, I caused to be introduced into the House of Representatives a bill which I drew for the appointment of a commission having the same general object and purpose as the bill which you contemplate. The especial feature was a little different. I did it on my own responsibility, but I did not do it without consulting others. I consulted the Commissioner of Patents. I consulted one or two of the Judges of the Supreme Court of the United States and other 
persons. The bill was referred to the House Committee, and they gave a hearing on it to me, and other gentlemen. The Commissioner of Patents attended, and he urged more especially in regard to his own department the importance of the bill, and had a great deal to say, especially on the subject of the establishment within the Patent Office, of a special tribunal, such as has been sketched in the paper that has been read this evening. The bill met with great favor with the House Committee, and they unanimously approved it, after making some modifications in a few of its details. They changed some of the provisions in respect to the compensation of the Commissioners and provided a suitable compensation for a secretary, and they made a distinct appropriation, I think, of the sum of forty thousand dollars to cover the entire expense. The bill was reported to the House, but it was overslaughed with thousands of other bills that never passed that Congress. I happened that winter to have a good many cases before the Committee, as counsel or associate counsel, and I became very intimately acquainted with the different members of the Committee from different parts of the country, and I am convinced that if this association, and the other body that has been referred to, which I cannot describe by its proper title, shall take up this subject and resolutely carry it before Congress in the mode in which you contemplate, that you can get the bill passed. That bill which I had some instrumentality in preparing fell to the ground, of course, with the expiration of that Congress. I had a conversation with Senator Platt, of Connecticut, who is the chairman of the Senate Committee on Patents, and he raised this objection, that however good a code or bill might be, prepared by such a commission, that when it came to be enacted, it would be loaded down with amendments that would kill it. Well, my answer to that was, that would depend on the ability of the Commissioners to make a consistent and harmonious code, and one that would address itself on its own merits to the general legislative mind, and that it would also depend upon the ability of the Commission to explain the changes which they contemplated, or the improvements which they contemplated, in a report to accompany the bill; and I thought that if that could be done a majority of both houses would see the wisdom of passing it as it was presented by the Commission, and not undertake to amend it, but let it go into operation and be amended as the progress of time 
should show amendments to be necessary. This matter was never before the Senate Committee. This was simply an informal and private conversation which I had with the Chairman. Now, sir, it would take me half the night to touch all the points, or half of them, on which it seems to me the time has come for this kind of action. My situation and occupation of late years have led me to bestow a great deal of attention to the course of the Supreme Court in the administration of the Patent Law. Unfortunately-I do not know how it has come about exactly,-but the present court has gone to very great lengths in overturning all the great doctrines of the Patent Law that were settled forty years ago, when I first began to practice-and that is more than forty years ago. There have been decisions, which of course must stand as the law, until Congress shall interfere and declare the law otherwise. Well, that is one great part of the task which such a Commission would have to perform. They would have to examine all these cases and see whether they are, or are not consistent with the fundamental principles of the law as it has been construed heretofore. The statute law is substantially the same to-day as it was, when enacted in 1833. There has not been any -very material change. But there is a very great departure in the doctrines that are held now by the judges of the Supreme Court, from what seemed to me to be the sound and true doctrines of the law, and I hope you gentlemen will go ahead and get your bill passed, and then secure as suitable a commission as you can. I have a copy of the bill of the last session, which I will hand to the President.* I suppose that your bill,

*In the House of Kepresentatives, March 24, I884. Mr. GreenLEAF introduced the following bill:

To provide for the revision, improvement, and amendment of the laws relating to patents for useful inventions.

Be it enacted by the Senate and House of Representatives of the United States of America in Congress assembled, That the President is hereby requested and authorized to appoint three commissioners, one of whom at least shall be a person learned in the law of patents for useful inventions, and a practitioner of ten years standing in the courts of the United States, whose duty it shall be to examine, revise, and report upon the laws of the United States relating to patents for useful inventions, the remedies for infringements of such patents, and the internal administration of the Patent Office, and to report such amendinents of the system as they may deem expedient, in a single code or in draughts of separate laws.

SEC. 2. That the said commissioners shall make their report within six days of the first day of the next session of Congress after the passage of this act.

SEC. 3. That the said commissioners shall each receive a compensation of five thousand dollars for their services, and an aliowance of eight dollars per day for their necessary traveling expenses when actually engaged in the business of the commission away from their respective residences. They 
which in some respects is a better one, yill go at once to the House Committee; and of all suggestions I should respectfully recommend that you avoid the appearance of aiming at any particular point, any particular change, in the present system of Patent Law more than others. The paper goes over a great deal of ground, specifies a great many different points. There would be differences of opinion, of course, about those different matters. With a great deal of it I agree. I do not know whether I should agree with every part of it, but if you can present your application in such a way as not to allow the Committee to have the idea that you have any axe to grind for yourselves, or anybody else, in respect to any specific question, why, I think there is no doubt but what you will succeed in carrying the measure that you wish to.

The President :- It has been very interesting indeed to have these remarks from a gentleman so well-known, and whose experience extends over a period of well nigh half a century. In listening to such mature advice, and in governing ourselves by it, we certainly can not go very far amiss. Mr. Curtis, in his remarks, made allusion to an interview that he had had with Senator Platt. I may state that a few days ago I wrote myself to Senator Platt, calling his attention to this movement which had been set on foot by the National Electric Light Association, and which we proposed to bring within our purview, and I asked his opinion of it, saying that we would be very glad, if possible, to have his attendance at the meeting. I would like to read his reply. It is as follows:

“U. S. Senate, Washington, Dec. 17, 1887.

"T. C. Martin, Esq., President American Institute Electric "Engineers, New York.

"Dear Sir:-I have your letter of the 15th, expressing your desire that I be present at your meeting next Tuesday evening in New York. It will be impossible for me to leave Washington at that time.

"With regard to the proposed revision or amendment of our

shall be allowed to appoint a secretary, who shall receive a compensation of one thousand two hundred dollars for his services.

SEc. 4. That the sum of twenty-five thousand dollars is hereby appropriated to pay the expenses of the said commission, including the compensation and traveling expenses of the commissioners, the compensation of their secretary. and their expenses of printing, such payments to be made by the Secretary of the Treasury, upon vouchers certified by the commissioners, at such times as they may present such vouchers.

SEC. 5. That this act shall take effect from and after its passage. 
Patent Law, I can only say, generally, that while I think some amendments are very desirable, it is very doubtful, first, whether such amendments as are desirable, can be obtained at the hands of Congress; and, second, whether any attempt to radically amend our Patent laws would not result in the passage of laws calculated to injure the interests of inventors and the public. I say this, because my observation leads me to believe that probably two-thirds of the members of Congress are more or less prejudiced against patents and against certain desirable features of the patent system, and during all my experience in the Senate, it has been my effort to prevent Congress from passing laws which would be disastrous. No man can predict the outcome of an effort to amend the Patent Law. It may result in what we deem the advantage of the public. It is quite as likely to result injuriously to the public. I have been made to feel very many times that perhaps it was better to bear the ills we have than to fly to others we know not of. In saying this, I do not mean to imply that $1 \mathrm{am}$ not in favor of amendments, but simply to indicate the danger that always confronts us when we attempt to legislate with reference to patents.

"Very truly yours,

$$
\text { (Signed.) "O. H. Platt." }
$$

We have a representative of Connecticut with us in person this evening. I refer to Mr. Albert H. Walker, and his views on this subject would be likely to interest us very greatly.

Mr. W ALKer :-Mr. Chairman and gentlemen-I have listened with great pleasure, as we all have, to him whom we regard as the father of us all; speaking of ourselves as patent lawyers, or as interested in the development of the useful arts. The pamphlet that I see in the hands of some of you, and which, I suppose, has been read by most of you, contains an article by myself, which sets forth the principal part of my views touching the desirability of revising the Patent laws. It will therefore not be expected that I will elaborate my opinions upon that subject on this occasion; but I shall be glad, with your permission, to make some observations touching the expediency of pressing Congress to take the proposed step toward revising those laws. I do not agree in the slightest with Senator Platt. My experience in the attempts that have been made to secure from Congress the revision of the Patent laws, dates back to a period considerably earlier than that of Senator Platt, and with all deference to him, I think it has been more extensive than his has been, because during his occupancy of a seat in the Senate, no such effort of any degree of seriousness has ever been made. Ten years ago the celebrated bill, 300, was before Congress-the 45th Con. 
gress. Its forerunner was before Congress eleven years agothe 44th Congress - and very strenuous effort was made to pass that bill. Very large amounts of money were expended in employing distinguished lawyers to apply to Congress and secure the passage of that bill. It was not favorable to the patent system as a science. It was advocated by men who had axes to grind. It was advocated by men of very great ability who had clients who contemplated plucking certain prospective prey of theirs, and it failed, because it was a bad bill; and I think that a bad bill upon the subject of the Patent laws can be relied upon to fail in the American Congress. A great many have failed and I think they all will fail. Why? Because there are so many intelligent men in Congress, and because there are so many intelligent men in the United States who can explain things to the intelligent men who are in Congress. If we are ever going to make an effort to secure a revision of the Patent Laws, no time is more opportune than this. I read this afternoon, on my way here from Hartford, an editorial published in the December number of the Electrical Engineer, taking the view of this subject which is taken by Senator Platt in his letter. The editor indicated in that editorial his opinion that a Congress, which sits pending a presidential campaign and pending the counting of an electoral vote, is a very inopportune Congress to which to apply for a revision of the Patent Laws. But half of our Congresses come within that category. Half of our Congresses sit in the last halves of presidential administrations, and the other half in the first halves of presidential administrations, and those Congresses which sit in the last halves of presidential administrations are generally understood to attend chiefly to presidential elections rather than to the public business; and for that reason the editor of the Electrical Engineer expressed the opinion that it is hopeless to expect anything in the way of valuable Patent Law amendment from the present Congress. I am inclined to agree with him, and therefore I advocate that this Congress be the Congress that be invited to pass the bill providing for a commission, and that the 51st Congress, which will not be trammeled by such considerations, be the Congress that be invited to enact the bill which shall be recommended by that Commission. It is impracticable,"in my judgment, to secure from any one Congress the passage of a bill to appoint a commission, and also the enactment of the legislation which may be recommended by that commission; because the 
time which passes after a particular Congress assembles and begins business, before that Congress adjourns, is less than fourteen months; and that time is too short in which to secure the passage of our bill or of any bill for the appointment of a commission, and for that commission to pass through its deliberations and produce its report and to have Congress intelligently act upon the bill which may be recommended by that commission. In point of fact, those three things never will be done in any one Congress. Therefore the obvious plan is to ask one Congress to enact a bill providing for a commission, and the succeeding Congress to pass upon the legislation that may be proposed by that commission; and that is the scheme of the bill which appears in your pamphlets as having been advocated by the National Electric Light Association. That bill is proposed to be introduced into the 50th Congress, and the report of the commission is proposed to be submitted to the 51st Congress, so that no time more opportune than the present will ever occur for us to move in this matter. Senator Platt has suggested the inexpediency of a commission, holding it more expedient to apply to Congress to pass particular legislation on the subject. That plan is far more likely to do harm than to do good, because such a particular bill, to amend the Patent Law in a particular way, is the very sort of a bill that will be loaded down with amendments. It will come before Congress with no responsible authorship back of it. It will be an anonymous bill. It will rest under the suspicion of having been gotten up by men with private interests to serve. It will be presented to the committees in Congress, and the committees in Congress will not understand the subject, and they will think they can improve the bill, and they will take a whack at it, and put on a patch here and cut out a piece there; and finally, when that bill is presented to Congress, it will resemble nothing in the heavens above, or in the earth beneath, or in the waters under the earth. And after it has been amended by the individual members, it will bear a still less resemblance to any of the works of nature or of true art; whereas a bill presented by a responsible, authoritative, respectable commission will have weight. It will remedy grievances which are justly complained of by those who are somewhat prejudiced against the Patent system, as well as remedy evils under which those labor who represent the interests of our inventors. Those bills that have been introduced for the purpose of striking a blow at the Patent 
system during the past five, six or eight years, have all been of one character. I have closely watched them. They are bills which provide that no suit for infringement shall be sustained against anybody for merely using a patented article, which he purchased without actual knowledge that it was covered by a patent. Those terrible grangers from the West, who are represented as being willing to come down on the Patent system the moment they are let loose, like the angel of death, have never made any attempts more extreme than that; and they have made their attempts a little more extreme than they would have made them, if they were instructed on the subject a little better. But they had a real grievance on that point, and members of Congress have thought they were serving their constituents splendidly by introducing bills providing that nobody shall be held liable for the use of a patented article that he purchased for himself without knowledge that it was covered by a patent. Now, those bills have been too broad and sweeping. They could not be scientifically introduced into the Patent Laws without working inharmonious results, and those results were not foreseen by the men who advocated them. Now, I believe firmly, that if an intelligent commission had this matter in hand, one of the things that commission would do, would be to draft a measure upon that topic, going as far as the just requirements of the grangers would carry them, and not going as far as the representatives of the grangers in Congress have gone; and that those sections thus drafted would meet that ground of complaint, and would be seen to meet that ground of complaint by the very men who have made the complaint. Now, I have heard a great deal ever since I attended before Committees of Congress, ten years ago, about a great deal of opposition to the Patent system. This opposition to the Patent system is like the fever and ague you had out West-it was never in the particular town you were in, but you could always find it in the next town. Now, it has happened to me to draw the pleadings, or otherwise participate in patent litigation in every state of the Union, except five, and to argue cases orally in fourteen of the states of the Union, and I have lived among a wide variety of people. When I was a small boy, my father took me from my New England birth-place to Wisconsin, into a purely agricultural community, a newly settled country, where the painted Indians used to whoop by our house in the summer time, and where there were no manufacturing interests, and I say to you gentlemen that I never 
yet met a solitary man in my life who was opposed to the fundamental principles of the patent system-not one individual. I have met all classes and conditions of men from Massachusetts to California, and I yet have to see the adult voter who is opposed to the underlying principles and general frame work of the Patent laws. We have not had a solitary line of legislation, good, bad or indifferent, on the subject of Patent laws, since 1875; and since 1879 there has been no serious attempt to remedy the evils under which the inventors of America have labored. This is a great wrong, and the United States Senators and the Members of Congress have much to answer for. I see nothing to fear whatever from the appointment of a commission, but everything to hope from it; and I firmly believe that if a commission was appointed, the head of which might be my own predecessor as a writer of Patent Law text-books, Mr. Curtis-if such a commission were appointed to sit as judges, to do justice according to their knowledge of Patent Law, between different classes and conditions of men, between the inventors and the users of inventions, the report of that commission would be seen to be so eminently fair, so eminently sound, that it would go through both Houses of Congress without serious opposition, without any attempts at amendment that would be more harmful than a fly upon the trunk of an elephant, and without any changes whatever. Whereas, if we continue to content ourselves, or endeavor to content ourselves with the outgrown clothes that we have tried to robe ourselves in during the past fifteen or twenty years, we will stumble along after a fashion, and the world will not collide with any other planet, and inventors will get some sort of reward for their inventions ; but there will be a great deal of trouble, a great deal of unnecessary loss, and a great deal that ought to be avoided. In these days, when the arts are being so perfected, it is disgraceful to the United States that the Patent laws are not also being perfected. What would anybody think of the suggestion to do away with dynamos by reason of the fact that they are more dangerous than a Morse telegraph sounder. In like manner, how can we estimate our courage at a high rate when we are at all restrained by the opinion of Senator Platt, or anybody else who entertains such an opinion, from doing what in us lies to bring to the attention of the American Congress the evils under which we and those we represent have long labored, and ask that those evils be remedied. 
Mr. Curtis:-Mr. Chairman, I may give my friend from Connecticut a single instance, such as he never met with. A great many years ago-before the war-there was a Senator in Con gress, from North Carolina, Mr. Badger. He was a very eminent lawyer,-a general lawyer-and a most admirable person. I was conversing with him one day about a bill that was before Congress-I do not recollect whether it was a special bill or whatbut it had relation to some changes in the Patent Law. Well, he said, all I know about the Patent Law is this. Some infernal Yankee comes down to my country and mouses around my back yard and looks over the fence, and he sees something in use there in my garden, and he calls out to me and says, "Stranger, I have got a patent on that; you will have to pay me ten dollars for the privilege of using it." That, he said, is all I know about the Patent Law, and all I want to know. Well, I said, Senator, you are here to legislate for the people of the United States; you are in the highest branch of the legislative department; now, that is not worthy of you or of the state that you represent. Now, you just take this subject and look into it and you will find that there is a great deal in it that you ought to know and that you ought to be able to give an intelligent vote upon. He did so, and he was entirely convinced that he ought to know something more about the subject than he did. That is the only instance of the kind that I have met with.

Mr. Phelps:-Mr. Chairman, I have a letter here from Mr. Kintner, which I will ask the Secretary to read, and after he has read it, I will have a word or two to say.

The Secretary then read the following letter:

"Mr. George M. Phelps,

$$
\begin{gathered}
\text { “265 Broadway, Rooms } 26 \text { and } 27, \\
\text { New YoRk, Dec. 17, } 1887 .
\end{gathered}
$$

"My deAr SIr:-

11 Wall Street, City.

"I am in receipt of a communication from Mr. R. W. Pope, Secretary of the Institute of Electrical Engineers, advising me of the discussion touching the question of a revision of the Patent Laws on the 20th instant, and inviting me to be present and express my views in relation thereto. I had hoped that it would be possible for me to be with you upon this most interesting occasion, but business engagements will keep me in Washington the greater part of next week. This matter is of momentous interest to all inventors and persons interested in patent property.

Some years ago, I had the honor to call the attention of the so- 
icety to the wants of the Patent Office and the necessities of material changes in the Patent Law. I have noted with interest all that has been done by the Institute, and am gratified at the fact that the committee appointed by it has succeeded in putting mattors in a tangible shape to go before Congress. While the scheme proposed by this committee is in my opinion entirely practicable, I have some hesitancy as to the feasibility of its presentation to Congress at this time, and am in hearty accord with the views expressed by you in your editorial in the December number of the Electrica Engineer.

During my official connection with the Patent Office as its Chief Clerk, I very naturally became pretty well versed with the political phases of all matters appertaining to the conduct of the bureau. It is needless for me to say here, that in matters of politics individual personal interests control individual members of Congress, and that upon the eve of a great national election, such as occurs next November, we cannot afford to run the risk of losing everything in a proposed change of existing laws. I, therefore, beg that you will present the following resolution to the society and urge its passage:

Resolved, That it is the sense of the Institute, that it is unwise at this time to seek by legislation to in any way modify the existing Patent system, and that any movement to that end should be postponed until after November 1st, 1888.

I am sure that this resolution will meet with the full approval of every one who has the good of the Patent system at heart.
Very respectfully yours,
C. J. Kintner."

Mr. Phelps:--Mr. Chairman, I present the letter at this time, because Mr. Kintner supplies a resolution and has requested that it be offered, and I offer it and move its adoption, in order to have a more definite thing before us to discuss. I have listened with great interest to Mr. Curtis and to Mr. Walker, but I am still of the opinion that it would be unwise to present the proposed bill to Congress. I think it is quite clear that there is no difference of opinion here as to the merit of the proposed changes-the changes sought to be made in the patent system through the presentation of such a bill. But in respect to the unfavorableness of the time and the public temper-I think there is much difference of opinion on that point. $\mathrm{We}$ had better educate public opinion further before attempting to obtain legislation. Mr. Walker has never met anybody who was opposed to patents. I have met a very considerable number of persons who have a distinct opinion unfavorable to the Patent Laws-unfavorable to any Patent Laws. I have heard a number of intelligent persons say, that we would be better off if the entire system were swept away; that if the improvement of machinery and 
methods and processes was left entirely to the competition of manufacturers, there would be sufficient incentive to develop and improve the arts.

Mr. Curtis :- Haven't they got to strike out a part of the Constitution of the United States in order to reach that ?

Mr. Phelps:-Isn't the provision that Congress may?

Mr. Cortis:- Yes, but it always has been considered an imperative duty.

Mr. Phelps:-Well, however unreasonable such opinions may be, there are a considerable number of people who hold them. I mention that because Mr. Walker seems never to have met an individual of that kind, and I happen to have met a number.

Mr. Curtis:- You may perhaps find a great many people that do not know there is such a provision in the Constitution.

Mr. Phelps:-Precisely. Inasmuch as the editorial in the Electrical Engineer has been referred to, I may perhaps repeat here some of the points therein presented. As to this point which is brought out by Mr. Curtis, that many people do not know anything about the constitutional provision for a patent system, there is an immense amount of ignorant prejudice in the public mind. The subject is not well understood; and in view of that and of the constant recurrence of these unsuccessful attempts which Mr. Walker has told us of, to interfere with the Patent Law, the indications are that if an opportunity be offered for renewing attacks all along the line, it would probably be availed of to a very considerable extent; and it is not at all unlikely that a very large number of members of Congress would be very greatly influenced by public opinion hostile to patents. If we could feel quite sure that the commission would be headed by Mr. Curtis, and composed of men like him and Mr. Steuart, we should have no hesitation as to their part of the work. The hesitation comes in as to what would be done with it after they had formulated it, and it seems to me we have little to expect from any early Congress. The bills to reform other features of the national polity have not always fared very well at the hands of Congress. I do not know why I should feel certain of having wise and discriminating action taken by that body upon a measure to reform the Patent Law.

Mr. W ALKER:-The last tariff law came from a commission.

Mr. A. C. Fow LER rose to speak.

The President:-I would like to ask Mr. Fowler to preface 
his remarks with a few of the statistics he has recently compiled with regard to patents covering electrical inventions.

Mr. Fowler:-I have understood from good authority that three-fourths of the manufacturing interests of this country are based on patents, and I think that in the electric art we can safely say it is nine-tenths, because nearly every electrical appliance is patented in one way or an other. Up to date there have been 375,000 patents and nearly 12,000 electrical patents, making onethirtieth of the entire number of patents granted by the United States electrical. Most of these electrical patents have been granted within the last ten or twelve years. There are about 25,000 applications patented every year-nearly that numberand about 30,000 filed. In the electric art there are about 4,000 applications a year, or about seventy-five per week, averaging about a dozen a day. I think this will show the importance of this subject to electrical men. That is the reason I mention it to-night. It would be safe to say that almost 10,000 of the 12,000 electrical patents that have been granted to date have been granted within the last ten or twelve years, averaging nearly a thousand electrical patents for each year during the last ten years. Before taking my seat I should like to say something upon the paper that has been read this evening. I stand here as a representative-I do not know but what the gentlemen may call it the Patent Office mill-but I have been through it and I have been in the electrical part of it. The gentleman, I think, has dropped into an error about the Patent Office paying all its expenses since it has been organized. In a paper which I had the pleasure of reading before you a year or so ago, I mentioned that an Assistant Commissioner had looked up this point. In years gone by, the printing that was done for the Patent Office was done by an appropriation of Congress and not out of the Patent Office fund. Recently the expenses of all printing have been deducted from the Patent Office fund. This Assistant Commissioner ten years ago, I think, ascertained that, including the cost of printing, the expenses of the Patent Office would have been about equal to the amount of the receipts. From the gentleman's remarks this evening, one would be led to believe that there was no such thing as an examination in the Patent Office for admission. I can tell you all here this evening that there are some examinations held in the Patent Office, and pretty hard ones too. I have seen graduates from the Yale 
Scientific School, from the Princeton Scientific School and from the various scientific schools of this country, and from West Point, come down to the Patent Office. They were going to get in, but I have seen a great many of them - the most of them-go back. The examinations they hold there are quite technical. I have been through them, and I have had to study very hard to get through them, and I started with a good scientific education. It has also been the practice of the Patent Office in years past, to make the examination include questions on Patent Law, and previously nearly all the questions were on Patent Law. Latterly they have been more on scientific subjects. For promotion in the Patent Office the questions are largely those of practice and Patent Law. The gentleman will find among the examiners a great many who are quite well versed in the law. There are in Washington three night schools turning out lawyers by the hundreds, and a great many examiners in the Patent Office are students in those law-schools. Now, a gentleman takes exception to one examiner ruling differently from another. You will find the same thing in the courts. The questions that arise in the Patent Office among examiners on applications, are not so much questions of law as they are questions of fact, and where you find questions of fact you will find men differ. It is an old saying, "So many men, so many opinions." It is about true in the Patent Office, and I do not see how it will be possible to harmonize in any way the rulings of examiners. Now I should think the gentleman, from his remarks, expects an ex parte proceeding to bind every one. It is well known that an application for a patent is an ex parte proceeding. It is not contested at all, and it is no wonder that they are some times overturned in the courts, and I think there is always a presumption in favor of a patent. I think the courts recognize a prima facie right when there is a patent. This question of Patent Office reform, is a question that has been studied within the Patent Office itself. The examiners there have made a great study of it, and they have thought this question over. Some years ago they took steps in this direction. It was in the particular direction of an increase of salary though, and of course that was considered a salary grab and it was not very successful. The gentleman, I think, has enumerated a large number of objections to the Patent laws that are highly visionary. It strikes me that the system, as a system with some few exceptions, is 
quite a good one. I heartily concur with him in the wisdom of establishing a Patent Court, and I think he will find the Patent Office itself believes in such a thing. Almost every one believes that the judicial functions of the Commissioner should be taken away and his office made purely executive. It strikes me, as far as the Patent Office is concerned, there are only two things the matter with it. One thing is the inadequate pay of examiners. If the pay of examiners is increased, say doubled-I mean all through the assistants-the tendency will be that men will stay there, and a man that has been any time in the examining corps can perform three or four times the amount of work that one who has been there for a few years can do. It strikes me that this is the one thing needed in the Patent Office, increased pay, and there might be an increase of force. As to the appointment of a commission, it seems to me that the Patent Law could be revised by direct application to Congress. There is a standing committee of the House, and there is a standing committee of the Senate, and the Chairman of the Senate Committee is Ex-Secretary Teller, of the Interior Department, who knows all the Patent Office workings, and who has, in times gone by, had a great many cases appealed to him from the Patent Office, before his jurisdiction was overruled by the Supreme Court of the District of Columbia ; and I think that if the National Electric Light Association, or the electrical men, were to appoint a committee to confer with the Patent Committee of the Senate or of the House, that this could be effected more readily than by appointing a commission. It is a more direct application of power than the other way, and I think we all believe in applying power just as direct as possible.

Mr. Phelps :-Mr. Chairman, on one point I wish to add to what I have said. I have had some conferences with other persons in taking a position on this matter. I have not trusted merely in my own views and apprehensions; I have been told by an attorney of prominence and large experience in patents, as well as other branches of the law, that he went to Washington some two or three years ago, with the express purpose of initiating a measure to remove the very objectionable limitation of United States patents by foreign patents, and that having consulted with various persons, in and out of Congress, with respect to the matter, he concluded that he had better say nothing whatsoever about it; better drop it. In his judgment there was a danger 
then, of inviting attacks on the patent system, through amendments and otherwise, even in respect to such a specific measure as that alone. I confess, that incident has influenced my mind very considerably in forming an opinion upon the expediency of the measure before us.

Mr. Thomas D. Lockwood:-I stand before you this evening the representative of perhaps the best contested patent in the world-the Bell telephone patent of 1876 , and yet I like the $\mathrm{Pa}$ tent Law of the United States. I am not in the best condition to talk, because I have not heard the previous discussion, and I have not heard the paper, and I have just come from a dinner of about fourteen courses. Nevertheless, as the last seven years of my life have been spent with greater or less success in studying patents, I thought it right that I should say a word. With all the evils of the Patent Law of the United States, it is yet the best patent law in the world, and my experience is, that the Patent Law is not one-tenth as immoral as patentees themselves are. One man gets a patent for a steam engine. It is the first time, perhaps, that a steam engine has ever been invented. Another man gets a patent for a crank $A$, fastened down to the end of the main shaft $B$, and attached to the reciprocating connecting rod $C$, with a brass bushing in it, $D$; and the second man cannot comprehend for the life of him, why he has not got the right to use the steam engine, and he goes ahead and uses the steam engine, and a suit in equity is brought against him, and when a preliminary injunction is obtained, he poses before the world as a martyr to inefficient Patent laws; and then he goes to work and makes a slight variation in his patent, and gets perhaps a new element in his same old claim, and goes on infringing, and he is prosecuted again, and is enjoined again, and he poses before the world as a double martyr, and then gets a few more of his kind together, and they form an association for the protection of patentees. Then a few gentlemen, who really are patentees of the first order, think it would be a good thing to be protected also, and for the sake of their own virtuous patents, they combine themselves with the immoral patentees, and get a pretty good lawyer,sometimes a first-class lawyer, to frame a bill for the amendment of the Patent Law. In any event a bill is introduced for the protection of the innocent purchaser, and the innocent purchaser, nine-tenths of the time, knows very well that he is purchasing a patented article, because he has got the patent stamp very likely so emblazoned on one side of it that he cannot put it straight on the wall to save his life, 
but it has got to be hung bias. For these reasons, and many more reasons, I believe that we had better let well enough alone. I have noticed in the last seven years that whenever Congress goes to interfere with the Patent Law, they interfere with it the wrong way. Two-thirds of our Congressmen have got the notion which prevails in Wisconsin and Minnesota and the northern side of Dakota and Idaho, and few more places like that, that the patent system is nothing more or less than a system of wholesale swindling; and I was very glad to see by the Supreme Court decision last May, on the driven well patent, that the Supreme Court of the United States was not going to be influenced by popular notions or popular sentiments. I was glad to see that the Supreme Court could sustain a righteous re-issue. Even now the present Congress, which has not been in existence much more than a week, has begun to get in its work. I noticed last Friday morning that the regular innocent purchaser bill had already started on its march. I am very much of the opinion of Mr. Phelps and of Mr. Kintner, that at the present time it would be unwise to try to get any patent legislation. I am sure that if we stir the matter up we shall stir it more than we want to. If we get a commission, our worthy President, with the best intentions in the world, will nominate two commissioners from Michigan, and two commissioners from Indiana, and one commissioner from Ohio, and I am sure that that commission will consider it its duty to point out what one gentleman very forcibly did this evening, and say that the Constitution does not provide for a Patent Law ; it only provides that there may be a Patent Law, and they will condemn by ignoring that article of the Constitution which intimates that, if there is a Patent Law, it shall be to promote the arts and sciences. I am very glad that in these days of corruption, of judicial corruption, we have in the Courts of Equity upright judges; judges that are well versed in the law, in Patent Law, and who usually keep that provision of the Constitution before their eyes, and keep the idea of that article of the Constitution before their eyes, that a Patent Law is not to oppress people who use useful instruments, is not to provide that certain advantages and certain monopolies shall be given to certain people, but that in consideration of some useful thing furnished by an American inventor, that man shall be protected in the manufacture of his invention for a certain limited period. Now, with respect to the Patent Office, we cannot deny that 
there is a good deal of inequality of practice, notwithstanding the eloquent defence made by the gentleman on my left. Those of us, who have practiced before the Patent Office, have sometimes had the ill-fortune to have a case before three successive commissioners, either by an interference or by a double interference, or by some patentee who comes in at the very last minute, or by the inability of some examiner to distinguish between matters of form-matters of law-and the real subject of the case in the class of electricity. Since I have begun to send applications to the Patent Office, we have had the immortal Zenas Fisk Wilbur as first examiner in the electric class. We have had H. C. Townsend. We have had Dr. F. L. Freeman. We have had Mr. C. J. Kintner; and now we have Mr. Brown. Every one of these examiners, to my certain knowledge, has made different rulings upon the same point with the best intentions in the world. Mr. Wilbur used to make rulings, I think, that would help his own pocket out. Mr. Townsend was about as fair a man as I ever knew. Dr. Freeman was first class. Mr. Kintner always recognized the difficulty of formulating a proper electrical claim and allowed considerable latitude. $\mathrm{Mr}$. Brown, filled from the sole of his foot to the crown of his head with law, but knowing very little about electricity, is disposed to stickle for matters of form. It may be that the gentleman is here. If so, I assure him that I do not mean any disrespect; but he came to the class of electricity from the class which included chamber-ware. Now, how can a gentleman, no matter how good a lawyer he is, become an accomplished electrician in the twinkling of an eye, simply by being transferred from one part of the Patent Office to another? I do not know. It may be that he passed the competitive examination spoken of. If so, I have nothing more to say. If he passed it, all is well. I hope when Mr. Brown has fully learned electricity, and learned it well, that he will stay there, and that by that time we shall have some provision, either with law or without law, whereby examiners are well paid if they are good ones. I have nothing to say against Mr. Brown's rulings. They have been fair as far as I have seen. He seems to have a disposition to do right in so far as he knows it; but it would be a benefit, if we could get some uniformity and if we could get Congress to allow the $\mathrm{Pa}$ tent Office to spend the money which the Patent Office earns. Once more, I wish to express my opinion that it is not wise in 
the year before the general election to stir up any general legislation on patents, and I do not think that a commission is the best way to do it.

I think we shall have to go straight to Congress and get some kind of law which is formulated after mature deliberation and consideration by all those having an interest-by a congress of patentees if you will, with the best legal talent we can get.

Mr. Frankland Jannus:-I have listened with a great deal of interest to all that has been said for and against the revision of patent law, and I want to add my mite. I do not think that after all that has been said there is much more to add relating to the Patent Law itself. I agree with the gentlemen who has just sat down, that it is a very excellent affair as it stands; and as the matter appears. to me there are only a few things that need immediate attention, but those I think are urgent. I refer first to the entire divorce that I think should exist between American and European applications. We do not pay much attention to European laws. They do not pay any attention at all to ours. And why we should be hampered by them I never could understand at all. Now there is no better illustration of the danger of meddling with the Patent Law than what occurs in connection with foreign patents. Take the matter of the International Convention. That whole thing is absolutely inoperative for the reason that our representative did not know the difference between the filing of an application and the granting of a patent. As I understand it to-day, if you can get a case into the office and if you can get it through inside of six months, then you can take advantage of the balance of the seven months, otherwise the provisions of the convention are of no use to anybody. That is just a trifling example of the intelligence and information displayed by our Legislators on patent matters. No doubt the person who conducted the United States negotiations was perfectly sincere in his intentions. But the result is not good. Then we want something in the matter of re-issues. Mr. Lockwood has referred to a righteous re-issue. It is hard to say what that is. It seems to me a re-issue is righteous when the Supreme Court of the United States says so, and not until then. It is a very hard thing to get Congress to decide what a law is after the United States Supreme Court has had a whack at it. Now I think that a great many of the difficulties and troubles from which we 
actually suffer exist in the Patent Office. I have thought so for a long time and think so still. Reform is needed and we do not want to go to Congress for that, because we will get nothing. If Congress would do anything about the rules of practice, I would like to have them, but I doubt very much that they will. I have never yet known an instance where an Examiner was ousted for incompetence, and there is not a man here to-night who has practiced before the Patent Office who does not know that there are lots who are incompetent. Many are competent, I admit that; but incompetent ones exist. There are men in prominent positions in the Patent Office to-day who got in before the examinations began. They could not pass a scientific examination to get in to save their lives, if they were once out, and the only way a man can do when he knows his application is being considered by such a person is to get a change of venue in some way or other.

We all appreciate the entire importance of a record of previous cases in considering the validity of a particular patent. We all know that we have to go to the original files; it is there we get the original information. We want to look at the references, etc. Now, it is a fact that when you go back a few years you cannot count upon a complete file in the records of the Patent Office. I do not mean to say there are none, but I mean that back of the few years the files are incomplete. They contain the specification and letters, and probably a printed copy of the specification, but no drawing. Then, as the record room is about a mile away from the file room, there is only one single mode in which you can get the whole case together, and that is, to buy copies of everything you want in order to be able to look at them all together for about ten minutes. I once called Commissioner Montgomery's attention to the matter. He said, "Why, certainly-Mr. Duryea, won't you see to it that these copies are put in these files?" I felt that I had accomplished something. I went up there again in a few weeks and asked somebody if he had heard of this being done. It had not been heard of. I went to see the Commissioner again. He scratched his head and seemed to try to recollect: "Oh, yes ; oh, yes," he said, "Mr. Jannus, if you will put that matter in writing, I shall be ever so much obliged to you." I proceeded to do so. In the course of a few days I received a 
very courteous reply which said, that the matter referred to in my communication of such and such a date, had been referred to a committee, consisting of the chief draughtsman, the chief clerk and one of the principal examiners, and that they had decided that, whilst it was very desirable that this thing should be done, still that there was no force at the disposal of the Commissioner with which to accomplish the same; that it was eminently desirable, but that it could not be done, and he kindly concluded with the suggestion that $I$ call the attention of his successor to the same thing. I do not know whether his successor has got around to it or whether he ever will, or whether I ever shall. I think that some of the surplus, of which we have all heard so much, ought to be applied to attending to that matter.

I remember once being particularly struck by the effect of the statement on my part, that the Patent Office was responsible for nothing and responsible to nobody. The more $I$ think of it the more I appreciate that that irresponsibility gives rise to a good many very peculiar actions. It does not make any difference how much an examiner impedes the progress of your case, there is absolutely no responsibility on his part. There is nothing he can do, judging from the history of the office, that will secure his dismissal or reprimand. The only thing you can do is to appeal. That, it seems to me, ought to be remedied in some way or other. A man goes to the Patent Office with a case; he is posted in the art and he knows it is new. His attorney knows it too, of course, as his client has told him. Well, the case is taken up by some junior, some new man, probably in the office only a week or two, which very often happens, especially in the class of electricity. References are not well considered, and the burden is thrown entirely upon the attorney and his client to demonstrate to the office, to explain to the examiner, what the reference does show, and then call attention by contrast, to what the application shows, the precise work for which the Government Examiner was paid. That is a thing of daily occurence. I think that after a man has shown evident incompetence he ought to be incontinently "fired." I think there are plenty of good men to be had. Now, it is a regular thing for a fellow to examine a case and fire a lot of drawings at you and let you fight it out yourself afterwards. That is not the intention of the rules. That is not what ought to be done. I do not say it is done in every case, but it is done in too many cases, and 
it is these things that keep the work of the office back and hamper and annoy everybody connected with it. As a result of such actions on the part of the office, I have seen inventors deliberately order their attorneys to take claims out after being advised that they could be eventually secured, by appeal if necessary.

The peculiar views taken by inventors of their patents, and some other fellow's patent, is very well illustrated by the gentleman who preceded me. And that is true. But that ought not to be the case with examiners, although it is. They take just precisely the opposite view. They think they are counsel for the public, and instead of seeing what is in an application, and really making an effort to cite references to show anticipatory matter, they simply think they can expand a reference to any extent and that is the end of it. If it is rejected they are glad. That ought not to be.

Then this shifting of examiners from division to division is another source of delay and trouble, as in the class of electricity, where the chief examiner comes from water closets to electricity. It practically blocks the progress of that class for a long time. Then, when you come to add his lack of familiarity with the subject, an overwhelming disposition for technicalities, why altogether, you get a very interesting combination.

Now, in the opposite branch of the office-chemistry-there is an examiner, a very nice fellow outside of the office, but then he is always ready to deny the operativeness of a process. He is not going to find out whether it is operative or not. The fact that he will in all probability be proved wrong, does not deter him. You have not proved it is operative. You have not submitted specimens, and that is the end of you until you do. I have cases there now and I know that they are operative. The man who says they are, is a man of fifty years experience; yet this man, with no experience at all outside his room, says it is not operative, and the case is clogged until it becomes convenient for my client to prove otherwise. I have heard it suggested by a friend who has been very highly spoken of here to-night, that the day of a close examination in the Patent Office was gone, that the system of examinationthe theoretical system at present in existence - is obsolete. His idea is that the examiner should take up a case, point out objections - insufficiency of description, and all 
those things just as he does now, and then cite all the references he has, tending to show lack of invention; that after receiving those references it should be the duty of the applicant to amend his case as he might see fit; take out his claim, limit it, expand it, do anything he chooses, and then send the case to issue. That struck me at first as a most iniquitous proposition; but I think it will bear consideration, because the Courts will be the ultimate tribunals before which that case will be settled. For when the office has cited its references. then that branch of the case should be closed and sent forward. The applicant takes the risk in it. The favorable dictum of the Patent Office does not hold before the Court. I think that there is where the responsibility falls in view of the fact that the Courts constitute the only ultimate tribunal. It is not customary for people now-a-days to put money in patents without at least looking at the file, and the moment that is done, they are in possession of the data upon which the Court would have to decide and upon which they might as well decide also.

Now, I think there is another point that we need to consider more and that is this question of trials before a jury. I think we are agreed that the average jury is not fit to pass upon a patent. It takes a great deal of study for men who make it a speciality. I think it would be better to impanel a jury of experts, and pay them as such and let them advise the Court. The trouble with expert testimony at the present day is, that you have the jury and also have the experts, and the experts for each side color their testimony just as much as they possibly can. Then the tribunal not only has to consider the facts in the case, but they have got to estimate just how much an expert can exaggerate, without doing anything more.

I certainly agree with Mr. Steuart that the Patent Law needs some revision, but I am a little doubtful whether this is the best time to do it. Some think it is, some think it is not. I think, if we were to go for two or three inoffensive amendments, we might get them. If that cannot be done, as many gentlemen seem to think, then I favor the plan of a commission, because going to Congress with individual bills always gives rise to the suspicion that the parties who go have an axe to grind. The question is, How can these lawyers afford to come here and ask for these things? People in Congress ask these questions as well as other people. The answer naturally is they are trying for legislation 
for some particular thing, and especially are politicians liable to those suspicions. They think of that first, last and all the time, judging from what they say, and for that reason I think the plan of a commission would be the best, because the matter can then be presented to Congress in an impartial manner. Whether this present time is or is not the best, $I$ do not know, but I think if it is decided to apply for a commission, that this time is as good as any other. It will certainly take time to consider the question, and to formulate what they want. I doubt very much whether the matter could be brought to the attention of Congress until after this bugaboo of the presidential election has passed.

Mr. Lockwood:-I crave your indulgence for one or two more remarks. Words would fail me if I should attempt to depict the interest with which I have listened to the remarks of the gentleman who spoke last; and while I cannot agree with every one of his propositions, I may say that I can cordially agree with some of them. For example, I can agree most cordially with his proposition that the aspect of our Patent Law, with relation to foreign patents, does need revision. But $I$ do not think that a commission is the best means of accomplishing it.

With respect to the re-issue question, I think that the gentleman, apparently, so well able to explain his ideas of what is right and what is wrong, could scarcely find any trouble in ascertaining for himself what is a proper re-issue and what is not a proper re-issue. If we stick to the definition of the statute as to what kind of a patent may be re-issued-that is a proper re-issue. If we take a re-issue patent that is re-issued, obviously after the state of the art is advanced up to a certain pitch, far beyond its reach at the time when the patent was originally issued, and in which the first patent is clearly so reconstructed as to show an attempt to cover subsequent improvements, that is an improper re-issue. I do not think the law needs any revision with respect to re-issues.

The gentleman said that he never heard of any incompetent examiner being dismissed. I never did either. I do not think anybody ever did. It is the competent examiners that get out of the Patent Office. It is the incompetent ones that stay in. But I would like to add a doxology to his remarks there. I think it is equally necessary that there should be some kind of an ex amining committee for attorneys. I never heard of an incompetent attorney being dismissed permanently. I have known 
a good many to be dismissed from one client but simply to catch on to another one. And it is a pretty safe rule I think to fight pretty shy of those gentlemen who flood you with circulars after you have got a patent. It strikes me that there is something in the matter of Patent Office tribunals that needs rectifying. I do not know how the law is going to get around it, because the patentee seems to think his rights are infringed, if he is not allowed to handle the tribunals of the Patent Office as he sees fit. If we get an adverse decision, we feel very badly if we cannot appeal to the board of examiners in chief, and so on. But I do not know with my present information where to take hold of this subject of a tribunal. I think that needs a little more attention perhaps than has been given to it. Now all of us who practice before the Patent Office or are interested in patents should be prepared to bear patiently with the custom of examiners who deal with applications in an impartial and square manner. If they allow a patent which afterwards turns out to have other references, and which is not new, I think we should remember that it is utterly impossible in the present state of knowledge, and in the large expanse of publications and of prior patents which they have to wade through, to cover the ground every time. We have got to take our chances in the matter; and those of us who have taken out patents for inventions know we have got to get out patents for the inventor by hook or crook. As a rule the inventor does not care whether the claim is valid or can be sustained or not. If he has got a patent he can easily sell it. My experience is, no matter how foolish a patent is, how unduly broad a patent is, how ridiculous a patent is, all you have got to do is to find somebody with more money than brains and you can sell that patent, and you can organize a company with seven millions of dollars of capital on it, just as easily as you can with the best invention ever made. So I think we must not be too hard on the examiners. There are a good many ways we can help them. As a rule an examiner is open to conviction; the average examiner is, I am sure. About five years ago I filed an application for a patent before a certain examiner, which I think I could have made to cover broadly the conversion of electricity of high potential to electricity of low potential, for the purpose of getting incandescent lamps from the high potential circuits by means of induction coils; and the examiner, he was honest, but he was not informed on the subject, and he said---"It cannot be done." $\mathrm{He}$ 
said there was no such thing ever heard of as working an induction coil backwards well; it was within the extent of my electrical knowledge that it could be done-that it had been done, for I had done it myself, and moreover, I knew that the conservation of energy would work almost any way backwards or forwards. But I had a gentleman for a client who was afraid to give me rope, and the application was put upon a shelf. In such cases as that the examiner is not to blame for sticking to his views; but the client is to blame for not sticking to his views. For my part rather than erase a claim out, to which I knew I was entitled, I would let it stay in the Patent Office until the crack of doom.

Mr. Fowler:--I think, if the National Electric Light Association were to present some bill in Congress, which would increase the pay of examiners say fifty or one hundred per eent., it would go farther towards removing the evils of the Patent Office than everything else combined. In one year we counted that from among the examiners twenty-three had resigned-about one-sixth of the whole corps. The Patent Office now is filled with new men. Until a man has examined for one year, he is absolutely worthless in the Patent Office. I have been troubled a great deal myself since I have been out of the office with these questions of form, and I know exactly what it means. If gentlemen here had any conception of the work that is thrown upon examiners, they would know what it means. It is a great deal easier to raise a question of form, than it is to go down and examine the merits of a case. These questions of form are raised by men who are so banked up with work that it is anything to get rid of a case. If the salaries of these men are raised, and men kept there who can perform three or four times the work that new or inexperienced men can perform, reform will follow. I was talking with an examiner, a friend of mine, whom I met in New York a few days ago, and he said this is the way he works-and I thought it was a very poor way-it is anything to shelve a case. He has little rollers-stamps - that he rolls across a sheet of paperdivision, process and product and everything else-ex parte something - he rolls them over the sheets and hands them over to the clerk, and she writes a letter. That case is got rid of. I was very much struck with this question of form when I was in the Patent Office. There was a case which had been on the merits twice to the board and once to the commissianer, and it was a case we were very much harassed about. It was a question whether the thing was 
patentable, and one of the gentlemen in charge asked me to take hold of the case and make an examination upon the merits. I took hold of it, spent some little time at it and I found two English patents for exactly the same thing, and yet the case had been appealed to the Board twice and to the Commissioner once upon the question whether the thing was patentable. That just illustrates the point exactly. They will raise these questions of form to get rid of the case rather than examine the merits, because it takes too long. They want to be up to date with the work as near as possible.

Now, this question of limiting American patents by foreign patents does not strike me as being such a terrible thing. It is easily gotten around. It is the popular impression that all foreign patents limit an American patent, and yet it is only so when a foreign patent is previously patented. It is easy enough to file your foreign patent on the same day that the American patent issues, and the foreign patent does not limit the American patent, nor does the American patent limit the foreign patent in any way.

I am a believer in compulsory licenses as they have them in England. I know my friend on the right will not agree with me in this. I do not think one man should be able to get a broad claim allowed and prevent improvers from using improvements. That is what the law of this country gives them. In England a Board of Commissioners ascertain how much a license is worth; and they make a man with a foundation patent give a license to another party, so that an improver can use his invention. There are many companies in this country who have valuable improvements locked up in their safes. In that way they impede progress. I have in mind one company where the managers do not want to change the machinery because of the cost, although there are a great many inventions in their line that are better than the devices they manufacture. They buy up the patents and put them in their safe.

Mr. JAnnus :- I did not have the slightest intention of reflecting upon the entire staff of the Patent Office, because I know there are plenty of good examiners; I merely referred to those that were not, and to the fact that, despite the examination for admission, the force is not as good as it might be. I fully agree with what has been said about raising salaries, and I fully endorse the proposition that that would, in a large measure, modify 
present troubles in that respect. They want more men, and they want to have them more competent. Both things are necessary.

Concerning the new tribunal that has been proposed, I think everybody has considered the question more or less, and I believe everybody considers it more or less of a good plan. I agree also with Mr. Lockwood that this proposition needs to be considered very carefully. As the matter now stands, a person who has lost his case before one tribunal would feel personally aggrieved if he had not the opportunity of carrying it to another.

In days gone by, the assistant commissioner was taken from the ranks of the office. To him matters of form were referred. That precedent has been overlooked and that office has been practically vacant-that is what it amounts to. The question of re-issues is a very serious one. I passed it over, as I did other matters, believing it to be almost too late to go into it; but there is one point in that question $I$ would like to bring up, that is, the trouble in the way of an inventor, in securing what has been apparently lost by a defective patent, principally owing to the fact that it is a conclusive presumption that everything that is shown in a patent and not claimed is patented. If there is any way of overcoming that, then we will have actually what re-issues were supposed to cover. I do not believe that the re-issue law was ever meant to cover a case where a man went in and expanded an application after he had found the desirability of doing so. I do not think it was ever intended, and the Supreme Court evidently does not; but I think that if re-issue is confined to the subject matter found in the claims actually patented, giving it perhaps a better expression or some greater scope, a scope evidently due to it, and that then the applicant can remove from the defective patent the subject matter of a different character which was not covered in those claims, then relief can be found. As the matter stands it is a fact, and I think it will not be denied, that it is almost impossible to do anything with an invention after it has been badly patented. But as I said before, you never know what is a good re-issue until the Supreme Court has passed upon it. That question I feel to be too deep and too serious for our discussion to-night and therefore will leave it.

Mr. J. A. Miller :-I should like to say a few words. I have 
practiced before the Patent Office since 1854, and I do not know that any attorney practicing before the office has been more unfortunate, particularly in one room, in his intercourse with examiners than I have been. I speak of the textile room. Now, I have felt all these difficulties which have been spoken of by the various gentlemen here and have suffered considerably. At times I was almost disgusted with the actions of some of the examiners, but about four or five years ago I had three very important cases which were rejected in Germany and I went to Germany to appeal. Since that I have been satisfied with our Patent Office and with the practice in our office.

Mr. Jannus :-An ex-commissioner had the same experience recently.

Mr. Miller:-As to raising the salaries of examiners as a whole, I never did believe in that. I believe more in the European system of putting a high premium on the higher grades. I believe in paying the chief examiners a very high salary, but I think the young men can get along with a lower salary, and I think the present salary is sufficient for them until they have striven and gained a higher position. There is another remark I wish to make on this question of a Court.

We have all suffered very much by appealing from the Board of Examiners-in-Chief to the Commissioner and not getting quite to the Commissioner. In fact we do not know where we are when we get there. The examiners-in-chief are very honest men, but they get into ruts. If you have an argument before them, you know just what you are to say and it depends on who is to write the opinion, and if you happen for instance to take the question of employer and employee, and get started wrong on that, you cannot win to save your life.

Mr. Davidson :-I submit there is no system for the administration of affairs among men that will not be open to numerous objections from-may I say-theoretical perfectionists. Now, the Patent system is not perfect; we will admit that. There are perhaps many ways in which it may be improved. There has been quite an extended discussion as to the imperfections of examiners. We attorneys are perhaps quite as much as the examiners tainted with original sin. We are not perfect. Our judicial system is not perfect. The question we must come back to is this-is not our Patent system as we have it to-day the best that we can get, 
with some trifling corrections, and would it be wise for us to open the door to a general revision of the entire system? Is it well to invite changes which will require interpretation, which will require decisions to mark down the lines upon which they are to be interpreted, and overthrow doctrines in regard to patents based upon some three thousand or more judicial decisions? I think not. As soon as a revision of the laws is invited by a commission such as has been suggested, every man with a hobby in regard to the Patent Law, will appear before the commission and seek to grind his own axe. We will have before such a commission all the gentlemen who are in favor of protecting innocent purchasers. It seems to me I may be permitted to bring the discussion to what I understand to be the real point of it, that is, the propriety of making an application to Congress for the revision of the laws. Everybody assumes there are some imperfections; I should think we ought to treat them like any other business enterprise. No business man goes to another and says, I have got a claim against you; I don't know just what it is, but if you will help me to find out I think we can get at it. That is no way to get at it. We ought to decide what we concede to be the points to be secured for the improvement of the patent system, and then when we know just what we want, ask for it; and let the manufacturing interests, and the inventors bring their influence to bear upon the politicians. I believe in practical statesmanship. I do not believe in in ideal statesmanship. Let us select those things which are obtainable and make a direct application for them.

Mr. Wheeler :-I think that some time ago Mr. Phelps introduced a resolution, and in view of what has been said, I would like to second it.

The President :- While the Secretary is finding that resolution, I think it would be simply due to Mr. Steuart to afford him the opportunity of replying to the remarks that have been made.

Mr. Steuart :-Gentlemen, I have very little to say in this matter. I came here for the purpose of hearing what you had to say, and I prepared my paper for the purpose of making a text for this discussion, and I am very glad you have so freely and so fully expressed your opinions. There seems to be a somewhat equal division of opinion with reference to the proper course of procedure. I cannot help adhering to my original 
view with reference to the best course. It seems to me that if we can introduce into Congress a bill providing for eertain specific changes in the law which is the result of the work of a competent commission, who have investigated the subject carefully, and who bring in a report which comes from neutral men, unbiased by any personal interest and unbiased by any special class-interest, in such a form that it cannot be considered as class legislation; that we will stand before Congress with a better chance of accomplishing the results that we have in view than we could possibly have were we to go now before Congress, or any other time, asking for specific changes in the law proposed by ourselves. I think much good could be obtained by a bill that would provide for any one of the suggested changes which have been discussed. If a bill were passed providing for an increase of salaries to the examiners, it would do great good. If a bill were passed for creating a tribunal it would do great good. But when we are going about the thing at all, it seems to me that we want to put ourselves on the floor of Congress in the strongest position that we can take there, and the way to do that, as well as I can understand it, is to go there with the report of a neutral commission, and we will have a better chance than we could possibly have with a bill prepared by any class of men, whether lawyers or manufacturers. I will say in conclusion that I think the resolution that has been introduced is unnecessary, because I do not know that it will have any special object or any special effect-any special purpose. The meeting of to-night was called for the purpose of having the discussion which we have here engaged in, and of seeing what was the best that could be done. It is preliminary in its character. There will be a convention of lawyers and manufacturers held in Washington the first week of January, which will be under the auspices of the Patent Bar Association of the City of Washington, and I will be very glad, and I am sure they will be very glad, if all of you who are interested in the subject will attend that Convention for the purpose of hearing the question discussed as elaborately as it will be there discussed. The meeting will last several days, and there will be representatives from several cities. I think, that in view of that meeting and of the very much more full and elaborate discussion that will there take place, any action upon this resolution at this time would be premature. 
The President :--I think it lies within my duty to say that the resolution says, "it is the sense of this society." This is a special meeting, and I do not think we could pledge the Institute one way or the other, and I would like to point out in addition to that, that we have on the Secretary's desk a bulk of correspondence from some of the leading inventors and patentees and patent experts of the country, embracing various opinions; and certainly, before we express a definite opinion one way or the other of the Institute, it would be well to know what lies in that correspondence which should guide our action in addition to what we have heard this evening. I merely throw that out by way of suggestion.

Upon motion of Mr. Fowler the resolution was laid upon the table.

The following communications were received from various gentlemen who were unable to be present at the meeting:

New YoRk, December 16th, 1887.

DeAR SIR :-Your communication of December 13th, in regard to a proposed revision of the Patent Law, is received.

It will, I regret, be impossible for me to attend on December 20th, a previous engagement preventing.

It is my opinion, however, that it would be exceedingly disadvantageous to attempt to meddle with the Patent Law at present. You are more likely to make it worse than better, by any proposed legislation. Nor do I think the plan of a commission would be a very feasible one. I doubt whether a commission, favorable to patents, could be appointed; and I doubt whether, if appointed, its recommendations would be adopted by Congress.

There is, however, a possible and simple improvement which would be greatly to the advantage of the patent system, and which would not involve the necessity of going to Congress. The present system of taking depositions in patent cases amounts, very frequently, to a substantial oppression of the weaker by the stronger, and, invariably, to a very great and unnecessary expense. The province of the court is constantly usurped by experts-witnesses are constantly asked in regard to matters which, legally, are totally immaterial.

In my experience, over one-half of the testimony in a patent case, on an average, is immaterial, and would be ruled out at a trial at Law. The reason of this is, that the testimony is taken before an irresponsible officer, without power to rule upon questions or answers. Very frequently the Examiner in Chan- 
cery is subequently appointed Master on the accounting, when he immediately has the very power of ruling on the questions which upon the last hearing he did not have. The testimony so taken before him, as Master, is competent to reverse the previous decision on the coming in of his report. I believe, of course, that the best system would be a trial of all patent cases in open court. This, however, is impracticable, owing to the lack of judicial force.

I believe the next best plan, and one that is perfectly feasible, is that all depositions in patent cases should be taken before a Master or Referee with power to rule upon the admission of evidence; and that his ruling should be final, unless an appeal should be taken therefrom, within a specified time, to the court; and upon such appeal I should give to the prevailing party substantial costs, so as to prevent the overburdening of the judges with useless and vexatious appeals. An appeal from the judge's ruling to lie, of course, as it does now, to the SupremeCourt of the Unnited States.

I have no doubt that the introduction of this system would decrease the cost of patent litigation, which is now burdensome, over one-half, and could but result in benefit both to litigants and to the courts. The records being much less voluminous would involve much less time for consideration in the courts, and consequently business could be more rapidly disposed of. This modification of the practice would, I know, from discussion, receive the approbation of many prominent members of the bar; and it is a change which could be made under a Supreme Court rule without the necessity of going to Congress at all.

Of course, I appreciate as much as any one, the numerous defects of the present system ; and I am sure that that system ought to be changed in many important particulars; but I likewise believe that it cannot be done at the present time, and that any interference by Congress with the Patent Law is more than likely to result in disaster.

$$
\text { Yours truly, }
$$

E. N. Dickerson, JR.

\section{W Ashington, D. C., Dec. 16, 1887.}

The subject of Mr. Steuart's paper on Revision of the Patent LAw is an important one, and I am glad you have extended to the absent members of the Institute an invitation to state their views.

Allow me briefly to state that I have no fault to find with our Patent Laws, but that I should like to see:

First: That the Commissioner and the Examiners should receive double their present salaries, so as to induce them to stay in service longer than they do now.

Second : That a Patent Court be established, constituted somewhat on the plan of the Supreme Court of the United States, who shall decide all patent questions, and whose decision shall be final. 
ThIRD: That no citizen of a foreign country shall obtain a United States patent for a longer period than a citizen of the United States can obtain in said foreign country.

Yours very truly,

E. Berliner.

Lewiston, Maine, Dec. 16, 1887.

I hope that in the discussion of Mr. Steuart's paper some one will again call attention to the point raised in an editorial in the Electrical Engineer for December. The probability is, that what we shall get will not be what we ask. And there are one or two features about the proposed changes which I hope Mr. Steuart will explain in greater detail.

For example; the testing laboratory, first suggested, I believe, by Mr. Kintner, and generally received with favor. I am unable to see how much could be done with it without giving to the examiners the privilege of requiring, whenever they saw fit, that the actual device should be brought before them, in complete working order. Would not this in many cases work great hardship ?

I understand the Electric Light Committee to recommend a special training for Patent Office employees, similar to that which army officers receive at West Point; but I do not remember that they suggest anything corresponding to the post-graduate course in Indian fighting taken by the West Point boys. It may be, that I radically misunderstand the committee, but it has seemed to me, that, when the skeleton they bring forward shall have been clothed with flesh by professional law-makers, it will take the form of a goverment school of Patent Law and Applied Science, whose graduates would receive a sort of sub-lieutenant's commission in the Patent Office.

Of course, any plan resembling this would in time fill the building with men specially trained for their work. But would they not be likely to be also thoroughly out of touch and out of sympathy with the practical life of the outside world, likely also to have a feeling of contemptuous dislike for the improperly educated majority of the inventors with whom they would be brought into relations, likely in short, to be prigs, pedants, obstructionists, adepts in the art of how not to do it?

Respectfully yours,

Almon Robinson.

Lynn, Mass., Dec. 17th, 1887.

Though I regret the inability to attend the special meeting, December 20 th, and take part therein, I am in hearty sympathy with any movement calculated to improve our Patent system. That it has some serious defects, is less of a suspicion than a fact. Just what these are, and how they are to be remedied, is far more 
difficult to determine. Some of the inequities of the system are, however, discovered without much difficulty and have often been pointed out.

Others, more difficult to locate and more difficult to appoint a remedy for, are none the less important.

The whole subject of the relations of home patents to foreign patents, of the rights of foreign and American inventors comparatively, one to the other, needs remodeling, in my opinion.

I believe that the standard of what constitutes an invention must, in the natural growth and development of the arts, gradually undergo a change, an elevation in such standard. It cannot be denied that to-day, with the experience and resources which have accumulated, many things are produced as the simple result of mechanical skill or skill not involving invention, and that very many such things become the subjects of patents, which, instead of benefiting the public by disclosure of something new and original, serve only to check legitimate growth of industry and harass the true inventors. How often, indeed, do we find inventors themselves applying for and taking out just such patents as involve no invention, but only aggregation and mechanical skill, knowing full well that they must do this in self-protection, to prevent being harassed in the development of their real inventions, by the pseudo inventor or quasi mechanical improver.

Many are the instances in which this is done, and for protection the inventor must not only take out a patent for his invention, but must give the time and energy and money to taking out his preventions of circumventions. For instance, one inventor takes out a patent for, say, a dynamo, belted or connected with a motor, in a certain combination, and shows the two belted together. Another inventor comes along and patents in the same combination a dynamo and a motor whose armatures are on the same shaft. Numerous such instances might be given. In fact, I have a case in mind in which the prior inventor shows both belting together two machines, and placing them on the same shaft, and using them in a certain combination; while another subsequently gets a claim limited to the same combination, but with the machines on the same shaft. It is not sufficient to say that such a claim is invalid, because it involves no invention; for the patent, having been issued after an examination of its novelty, has a certain warrant upon its face as containing invention, and with the sanction of the Patent Office.

As a consequence of this condition of affairs, it often happens that the intelligent inventor, or his attorney, who can and does discriminate as to what is invention and what is not, fails to claim what the less discriminating inventor or less careful attorney easily obtains. The result of this condition is to make the "claim everything," course the only safe one, assuming the Patent Office to be uniformly consistent in its rejections, an 
assumption which is theoretically, though probably not practically true, bearing in mind periods of time which have given rise to changes in the officers in charge.

There is much more which might be said, but I will content myself for the present with the above references to what I consider a defect arising out of our patent system, leaving to others to point out such other imperfections as may have come to them in their experience, and of which I shall be an interested student.

I seriously doubt whether any patent system can be devised which will not, in many particulars, become outgrown in a moderate period of years. Our present system seems, in many respects, to have been so outgrown, and if not revised, will become more outgrown as the needs of the industrial arts develop in new lines. What was formerly a real invention becomes, with the greater spread of knowledge and skill, merely the exercise of that knowledge and skill to fill a need for a new device, a need which in itself may not have existed prior to the time of its being filled. Indeed, this stage of progress seems to me to have been reached in certain fields of work.

Respectfully yours,

Elihe Thomson.

Baltimore, December 19th, 1887.

I regret that press of other business prevents my taking part in the discussion on a subject so important to the interests of inventors, and to the industrial and commercial welfare of the country in general, as is the movement about to be undertaken for a revision of the Patent Law.

That this law is sadly in need of revision, is patent to all who have had any experience in connection with it, and its principal defects are sufficiently well known to render it unnecessary to refer to them here, since this feature of the subject will doubtless receive its full share of attention at the hands of the able gentlemen who are assembled to do it justice.

There is one point in connection with this subject, however, that I think calls for concerted action on the part of the members of the Institute and inventors in general, inasmuch as it has an important bearing upon the question. I refer to the recently ratified International Convention for the Protection of Industrial Property, and its relation to the proposed revision of the Patent Law of the United States.

The inducements offered to American inventors by the Patent Laws of several of the more progressive foreign countries are now comparatively liberal, and it is but natural that, in view of the growing popular demand for inventions of merit both at home and abroad, the number of foreign patents taken out by citizens of the United States has largely increased. The remarkable and successful progress that has recently been made in the 
various applications of electricity, both in this country and in Europe, has opened up a new and profitable field for further effort in this direction, which electrical inventors in this country have not been slow to occupy. In fact, so great is the spirit of rivalry and competition in electrical matters at the present time, that the legal protection of an invention in several different countries is almost a matter of necessity in order to render it commercially valuable.

It has been customary for inventors in this country to file applications for foreign patents on the same day upon which the United States patent issued, or within a few days thereafter. This course was necessary, first, because of a provision in the United States Law (Section 4,887, Revised Statutes,) limiting the duration of the patent, if the invention is first patented in a foreign country. (As the date of filing is also the date of patent in the principal foreign countries, this fact has been construed as being sufficient to cause a limitation of the United States patent.) Second, because in several of the foreign countries a valid patent cannot be obtained, if a description of the invention becomes accessible to the public before the specification is officially filed. The compulsory filing of the foreign cases before the issue of the United States patent, under the provisions just cited, is a serious hardship to the inventor, because it necessitates the expenditure of a large sum for patents before he has had an opportunity to test the public feeling in regard to the usefulness or value of his invention, or the probable demand for it in those countries in which he purposes applying for letters patent. Furthermore, if an inventor intends to apply for foreign patents upon an invention pending in the United States Patent Office, he is compelled to abstain from doing so until after the various and sometimes tedious delays that frequently occur before the case is finally allowed and passed to issue. Moreover, an inventor is prohibited during the pendency of his United States application from publishing an account of his invention or discovery in order to publicly establish his claim thereto, or for any other purpose, because of the risk of losing or endangering the validity of the foreign patents when they are applied for.

Among the provisions of the International Convention for the Protection of Industrial Property, the outcome of a conference held in Paris by the delegates of several European countries for the purpose of introducing certain reforms into the various patent systems with a view to promoting harmony between the same, is a clause allowing an applicant in any one country a period of six months (an additional month being added for countries across the sea,) from the date of filing his application, within which to file the same in any other country belonging to the Union, and that during such period his rights shall not be invalidated by any publication or public use of the invention. Unfortunately, while the intention of the conference was good, the 
clause under discussion does not conform to the United States patent system, and is directly in opposition to the statutes as they now exist and in accordance with which patents in this country are issued. Indeed, it is a question whether, if the recent adoption of the articles of confederation by the United States are binding, the rights heretofore enjoyed by American inventors are not further restricted, since unless foreign application is made within seven months from the date of filing in this country, the foreign patent may be refused or invalidated. If this be the case, it is needless to say that fully nine-tenths of all the electrical cases now on file in the United States Patent Office are debarred from foreign protection in any of the countries of the Union, and the electrical division is now about six months behind on new work.

It is clear that such a state of affairs cannot long be allowed to continue, and it is high time that the entire patent system, not only of this, but also those of other countries, be placed on a firm and reliable footing. This can best be done by taking steps towards properly amending the provisions of the International Convention, so as to adapt the same to the requirements of our patent system, and these steps should be taken either separately or in conjunction with the proposed revision of the United States Patent Law. The international phase of the question will probably permit of a more ready solution by avoiding the attacks that may be made upon our present patent system, if the matter is taken up by Congress in its local bearing only, while by having proper representation at the next International Conference, sufficient progress may be made to introduce a number of important changes for the better without the necessity of re-opening the entire subject.

With regard to the changes to be made, I would respectfully suggest, first, that the latter part of section 4,887, Revised Statutes, before referred to, be stricken out, as it is of no particular advantage and is detrimental to the interests of American as well as foreign inventors. Second, that that action of the International Convention relating to the grant of a period of six months from date of filing in one country within which applications must be filed in other countries, be amended so as to allow applicants twelve months from the date of publication of the invention in any country of the Union, during which the invention will be protected as at present provided for. This will give an inventor one year after publication of his invention, whether as a patent or in a newspaper, within which to file his foreign applications, and would also enable him, if he so desired, to make foreign applications during the pendency of the United States application, which is sometimes of great importance, especially in case of any delay in the United States office, as in the event of interference proceedings and the like. Another point that might be touched upon in an international treaty is the abolish- 
ment of annuities, and if possible, the further reduction of foreign patent fees. Also the erasure of all laws relating to the "working" of patented inventions within a specified time. It is to the self-interest of the owners of a patent to work the same as early as possible if it is worth working at all.

Very respectfully,

\section{EliAS E. Ries.}

New YoRK, Dec. 20th, 1887.

I regret very much that I shall be unable to be present at the reading of Mr. Steuart's paper on the Revision of the Patent Law, and to listen to the discussion that will follow. The subject is one that cannot fail to command attention from all who are interested in any way in inventions, and especially electrical inventions. The growth of the electrical arts is so recent that its history and its causes can be traced with comparative certainty; and no one who has made the slightest inquiry in this direction, can have missed the conclusion that our patent system has been the most important factor in the development of the arts of electricity. To such an extent is this the case that a true friend of the cause might well deprecate any changes of the law, certainly any sweeping ones, as being fraught with more danger than the present condition of things. There are, however, certain matters of Patent Office administration that ought to be corrected, and there are certain tendencies of legal interpretation, adverse to patents, which can only be set right by amendments of the statutes. . The needs of the Patent Office in the way of room and examining and clerical force, have been long appreciated by inventors, and, for that matter, have been forced upon the attention of Congress by every Commissioner for the last twenty years.

How to make the practice of the office uniform, is another question of great importance. One Commissioner, at least, tried to accomplish this by forming a court of consultation within the office itself. Discussions were had between the different examiners in the presence of the Commissioner, and he gave the full influence of his authority to bringing them to harmony, but I understand that very little came of it. I believe that something in the nature of the Patent Court, proposed by the National Electric Light Association, is the best thing yet brought forward for securing the result.

These and other matters of importance, will no doubt be fully discussed at the meeting to-night.

Another thing, however, which will be called to your attention, seems to me of supreme importance. It relates to the trend of recent Court decisions in re-issue cases. I do not refer to the two years' limitation, but to the dictum that an inventor is presumed to dedicate to the public all that the incapacity of his attorney or the stubbornness of the examiner causes to be left 
out of the claims. Down to the present time, this has been asserted only in re-issue cases. Carried, however, to its logical issue, it would apply also to original patents and would call for a strict interpretation of every patent claim, by itself considered, and without regard to the specification. This, if not already the confirmed rule of interpretation, will be the inevitable result of the present tendencies. The claim must stand by itself, and, whatever the specification may say, it will not broaden a claim; everything not clearly claimed, will be regarded as abandoned to to the public. Two eitations will show what I mean. "But it must be remembered that the claim of a specific device or combination, and an omission to claim other devices or combinations, apparent on the face of the patent, are, in law, a dedication to the public of that which is not claimed. It is a declaration that that which is not claimed is either not the patentee's invention, or, if his, he dedicates it to the public." Miller vs. Bridgeport Brass Company.

And: "It is doubtful whether a re-issue patent can be sustained in any cases where it contains claims that have once been formally disclaimed by the patentee or rejected with his acquiesence, and he has consented to such rejection in order to obtain his patent." Leggett vs. Avery.

Now, what I wish to say in view of all this is, that it is unjust in the highest degree to hold an inventor responsible for the errors of judgment or the obstinacy of Patent Office examiners. I do not believe that any just complaint can be made, if inventors are held strictly accountable for the mistakes or incapacity of their solicitors; this is a matter they must see to for themselves. But it will go hard if the Government does not also make itself responsible for its own representatives. When a man puts in an application with narrow claims and makes no attempt to get more, let him suffer for it, unless he takes speedy measures to remedy the neglect. But when the record shows that an inventor has asserted his claims with enough persistence to prove himself in earnest, it certainly should not be charged to his account, if he is compelled to accept less than he deserves. Nor should it be necessary for every inventor to carry his case by successive appeals to the Court of last resort; it should be sufficient for it to appear that he yielded to a confirmed practice of the office.

There should be some law framed to make the Government entirely responsible for any abuse of power or any false judgments relating to patent applications on the part of examiners. I would have this extend also to cases of fraud. It is not good morals and ought not to be good law for one party to a fraud to repudiate the consequences of it. Whenever, by reason of fraud, a patent issues to one who is not the first inventor, the wrong can be righted by legal means already provided. But whether there be fraud or not, the Government cannot justly disclaim for 
itself a responsibility which it insists upon on the part of the inventor.

The injustice of the present ruling is apparent when one reflects that it is often impossible to get from the office, claims co-extensive with one's invention, and that there are penalties for delay in the prosecution of an application.

Respectfully,

\section{G. H. Stockbridge.}

\section{Philadelphia, Pa., December 21st, 1887.}

It was my intention to have spoken at the meeting last night on the patent question, but I was so engrossed with what others were saying, that I had forgotten that time was rapidly passing, and before I realized it, it was too late. As I have had some fifteen years experience in patent matters, not only as attorney, but as inventor also, (having at present about 3000 claims of my own pending before the electrical division alone), I write you the following, as I understand you will publish the letters, and my views may be of some use in remedying the present existing evil. I believe the entire defect lies in the Patent Office. It is seldom inventors obtain what they are entitled to, because, they are denied their rights by incompetent examiners who have no capacity for giving judicial decisions. I have been trying for years to get some of my numerous inventions protected by patents, but it is a difficult task. In one instance, I have been prosecuting a new and original invention for nine years and have not, as yet, been able to make the examiner appreciate the invention or grant me adequate claims for its protection. It has been before numerous principal examiners, all of whom have ruled in radically different manners. In another room, it took me six months in arguing a case to convince an examiner of one of the simplest laws in physics. In another case, which I appealed to the Commissioner, I have waited several years without getting a decision, the case having been before three Commissioners, and avoided by each. In another instance I have waited just about one year for a decision in an interference case which should have been given within a week at least after the argument. My experience is that the examiners are not qualified and never will be to such an extent as to invest in them the powers of judicial decisions.

My idea of the Patent system in the Patent Office should be as follows:

The present practice is good in its intents and purposes and is the best in the world. The examination should never be abolished. I have thought of many plans, but the following is the one I deem most fair and devoid of objectionable features.

An inventor (not promoter) must prepare his application with all the care with which it is now prepared, and in all material respects the same. The application or first government fee to be 
$\$ 5$ instead of $\$ 15$. The application is then examined upon its merits, as is now done; but with more care on the part of the examiners, who must cite all the pertinent references they can. The applicant can then amend, if he thinks proper, and ultimately the application is passed to issue. The final fee should not be over $\$ 5$ to print the patent, and all of the reference patents, etc. are to be printed upon the face of the patent so issued. By this means any one buying the patent can see for himself the scope of it, and can use his own judgment. The inventor or his attorney could take any claim they thought right and eliminate or amend only those upon which there is no doubt of anticipation. The excuminers would have no option in the matter, as should be, for in most cases they are incompetent to judge; but any inventor taking too much is liable to make his patent invalid in part or whole; and if the former, he would lose costs in any suit, as is now the case with any invalid claim sued upon. The courts would then be the only judge between the public and the patentee or owner of the patent. The interference proceedings would take place to prove priority of invention when two applications claiming the same invention were pending at the same time, and the time consumed in an examination would give a distant inventor every opportunity for a fair chance to prove priority. Where a patent has been issued, and another inventor claims the same thing, he may obtain his patent if he so insists, but it will have the reference of the other or prior patent upon its face, and by this means the contest will be carried to the courts once and for all. No fair law can exist where the first inventor can lose his rights by circumstances over which he has no control. By this system we would have all inventions published and properly placed on record for future generations, and the arts could not become lost. Putting this system into effect would not require many changes in the present system of the Patent Office. The appeals would remain the same, except that the appeals on the merits of an ex parte application would not exist. The examiners would be required to do all that they are really capable of doing, and that is finding the references. They should have no judicial powers on the merits of an applicacation other than to clearly express their opinion as a matter of record in the files.

I think such a system is about as near perfect as it could be made.

Mr. Steuart's proposition to allow the owners of a patent to reissue without the consent of the inventor is fundamentally wrong, because in many instances the applicant, to elucidate his own invention, often shows other inventors' inventions without making any attempt at claiming them. If the owners were allowed to re-issue without the consent of the inventor, they would undoubtedly take advantage of this state of affairs. As to foreign patents limiting the life of the American patents, I am of the opinion 
that it was always intended, and should be so construed that there will be no limitation if the American patent is applied for before the application for the foreign patent.

I am in favor of a suitable Patent Court, but one which should only act on cases in matters involving interference questions and suits appealed from the Circuit Courts of the United States. I am strongly opposed to any system which will compel an inventor to take appeals to obtain that which he knows to be new, and which he has invented. Put the whole risk upon him and his attorney, with a full record of the patents showing the art printed upon the face of the patent, and I think that little trouble will arise from claiming too much, and nearly all of the trouble of claiming too little will be removed. The Supreme Court and the Commissioner of Patents should be relieved entirely from judicial decisions upon questions of the merits of an application, and the examiners-in-chief could well be abolished if such a Patent Court existed with the removal of judicial powers from the primary examiners.

Very truly,

R. M. HUNTER.

New York, Dec. 24th, 1887.

In response to your request for an expression of opinion on the "Revision of the Patent Law," I must confess that the reform of the patent system has not impressed itself upon my mind as one of the crying needs of the day. Certain sections of the Patent Law, such as sec. 4887 on the limitation of the terms of U. S. Patents by Foreign Patents previously granted, and sec. 4916 on re-issues, have perhaps seemed to work some injustice in individual cases, but they are the exceptions, I think, and no human-made law is so perfect as to work absolute justice for all. I have read criticisms from time to time on supposed defects in the U. S. Patent Law, as it stands to-day, but none of those criticisms has made it very clear how the law is to be bettered in any vital respect. For my part, I do not recognize the urgency for, or the advisability of tinkering at the statutes.

With regard to the proposed "Bill to Establish a Commission to Revise the Patent Laws of the United States," I have not, for the above reasons, given the subject very serious consideration. I may say, however, that neither the necessity for, nor the usefulness of such a commission has commended itself to me.

In all probability the members appointed on this Commission would be men who would come to their task, more or less ignorant of Patent Law, and the little they would be able to learn of the niceties of that law during their brief term of office would not make their proposed revision of it of great value.

Whatever their report and whatever their proposed bill might be, however, the whole subject would have to be thrashed over again before the Committees on Patents of the House and Senate. 
Why should not those who are to edify the Commission, submit their views to the Committees on Patents of the Senate and House, in the first place, since those committees exist for the same purpose as that for which the Commission would exist? The proposed Commission therefore would only be an incumbrance (expensive in both time and money) in the way of reform, if reform is needed.

$$
\begin{aligned}
& \text { Truly yours, } \\
& \text { Hebert Howson, } \\
& \text { of Howson \& Howson. }
\end{aligned}
$$

\section{New York, Dec. 22, 1887.}

I enclose a summary and dissection of the various amendments to the Patent Law, first submitted to the Senate and House Committees of the 48th Congress, together with the authorities for the several amendments. This plan of dissection has been found convenient to those members of the Committee who have not time for critical consideration and comparison of the several provisions of the proposed amendments.

A most interesting point, which was in fact the essence of the "Gramme case," which did not obtain presentation at the hearing. before Judge Blatchford, but upon which he subsequently consented to a re-hearing of the case, is this. It was determined that the United States Patent was void, having expired with the "earliest foreign patent," which was the Austrian, a "secret patent," so-called, and counsel contended that because the patent was secret, that therefore it was not "patent," or due notice or publication or anticipation as to the United States inventor. But in this case the inventor was the same, and the secrecy of the Austrian patent was not material. This theory so nearly approximated the real merits as to obscure them, the fact being that the so-called secret patent of Austria is not a patent at all in the sense contemplated by the American law. It is merely a caveat, and until a patent is published under the forms of the law, it has no other operation or force than a caveat, and if never published, it never acquires the characteristics of a patent.

Accordingly, there was never, during the life of the Austrian Gramme patent, a moment when Gramme could have stopped the manufacture of his machines, or collected royalty or damage from any manufacturer, any more than the American inventor could obtain such protection for an invention as to which caveat had been filed, but a patent never taken.

The mere labeling of a foreign caveat "patent" or "brevet," ought not to invest it in American law with qualities which it does not in fact possess.

Yours faithfully,

Rowland R. Hazard. 
Mr. Frank R. Harding presented a very earnest tribute to the importance of the patent system in which he argued that the future welfare of the country depended in a great measure upon the perfection of our patent system. That there should be a separate department of patents because the system was selfsupporting; that the Commissioner, Assistant Commissioner, primary and assistant examiners and examiners-in-chief should hold life positions.

He criticised the faulty classification in the office, claiming that unnecessary and serious delays occur by reason of a case being first placed in a wrong division where it may be pigeon-holed for six months, and is examined in its regular course only to be transferred to another division where it is again delayed. 